http://dx.doi.org/10.7833/116-1-1336

\title{
LAND, FARMING AND SOCIO-ECONOMIC DEVELOPMENT IN YEHUD: A QUEST FOR SUSTAINABLE DEVELOPMENT TOWARDS POVERTY REDUCTION IN ZIMBABWE ${ }^{1}$
}

\author{
Temba Rugwiji \\ University of Venda
}

\begin{abstract}
The Hebrew Bible portrays the view that the Jewish lifestyle was predominantly agrarian. The ideology that Jewish socio-economic survival depended largely on subsistence farming is a depiction that the biblical text presents in terms of 'themes' pertaining to agriculture, such as: land tax, temple-tax, sheep, goats, cattle, and slaughtering and sacrificing animals. Significant archaeological discoveries to date have illumined the claim that agricultural production was critical in the sustenance of socio-economic life for both household consumption and national demand in the ancient Near East (hereafter, ANE). First, although issues surrounding land and socio-economic development (hereafter, SED) during the pre-monarchic, monarchic, and exilic periods as depicted in the biblical text will be considered, the main focus of the present discourse is the Judean postexilic period. In this essay, postexilic literature (e.g. Trito-Isaiah, Ezra-Nehemiah, Zechariah, Haggai, Malachi, etc.) will be explored. Second, this study employs an approach called 'hermeneutics of appropriation' in which significant 'themes' which fondled issues of land and farming in ancient Israel are investigated in view of the dynamics surrounding the land debate in post-independence Zimbabwe. Third, it is argued that in spite of the turbulence that has plagued the Zimbabwean economy in recent years, agriculture continues to play a pivotal role in averting starvation in the country. Fourth, this article concludes with a 'theology of reconstruction' in which strategies towards maximum utilisation of land, sustainable development and poverty reduction are explored.
\end{abstract}

Key Words: Land; Agriculture; Postexilic Literature; Socio-Economic Development; Poverty Reduction; Theology of Reconstruction

\section{Introduction}

The biblical text depicts the notion that the Jews were generally agrarian; they survived on subsistence farming. Several biblical references could be cited which attest to this view. For example, Genesis 2:15; 4:2-3 talks of tilling the ground; Deuteronomy 33:24 talks of the abundance of grapes and olives in Israel; every year King Solomon used to send quantities of wheat to Hiram in exchange for timber (1 Kings 5:11); several references to productive soils are also made (Psalms 1:3; 65:10; Prov. 31:1; Isaiah 30:25; 32:2; Hosea 12:11); wheat for trade was also shipped to the Tyrians (Ezek. 27:17). Use of animals in everyday functions was also critical. It is stated that sheaves were spread on a flat rock or prepared on

This discussion is drawn largely from the author's PhD thesis. See Rugwiji, T (2013). Appropriating Judean Post-Exilic Literature in a Postcolonial Discourse: A Case for Zimbabwe. PhD thesis, University of South Africa, Pretoria. 
an earth threshing-floor. Animals were walked over the floor, dragging threshing sledges (Amos 1:3). Significant information about the excavation findings on the agricultural production practiced in ancient biblical lands (Cartwright, 2004:88), also sheds some light. Cartwright refers to Abu Hureyra, located in the valley of the Euphrates River, that was founded by a group of hunter-gatherers whose descendants went on to develop farming around 11000 years ago. Cartwright further observes that the site was excavated in 1972 73 by a multi-national team of archaeologists. Two successive villages were uncovered. The inhabitants of the village hunted local animals, notably the Persian gazelle, and foraged vegetation. A more complex method of food production was practiced by the people of the second village. They cultivated grain crops and kept cattle, sheep, goats and pigs (Cartwright, 2004:89).

It is also critical at this stage to study the location of Canaan (present-day Israel) within the broader ancient Mediterranean world, or rather still, the Semitic world in which the Tigris-Euphrates river system was situated. The Tigris-Euphrates river system was situated in the Fertile Crescent of the ANE world comprising Mesopotamia, the Assyrian Kingdom, Akkadia/Babylonia, Sumer, Syria and Canaan. In the modern-day, this region would include: Iraq, Kuwait, Syria, Turkey, Iran and Israel. Cultural practices and farming skills (together with trade) from Mesopotamia ${ }^{2}$ could have been exported to Israel through interaction among communities occupying this region. Voluminous contributions have been published to date on this finding, examples being: WF Albright (1940), JA Thompson (1964), RJ Forbes (1993), John Walton (2006) and Louis L Orlin (2007), among numerous others. It is therefore evident that Israel was part of the larger ANE world with which she probably exchanged civilisation, trade, culture, craft and skill. The depiction we get from the biblical narrative about Abraham as a sojourner is that he was an animal breeder who migrated from Ur of the Chaldeans (in southern Mesopotamia) and had plenty of livestock (Gen. 13:2). Joseph - who had assumed an influential position in Egypt - told King Pharaoh that his brothers were 'shepherds' (Gen. 46:34; Pinker 2009:151). It is evident from the biblical text as already shown above that the Judeans would grow all kinds of crops, such as grain, fruit and vegetables, both for family or household consumption and for sale on their pieces of land. They also kept animals such as: cattle, goats and sheep.

The main aim of the present study is to investigate the theme of land and narratives of farming in ancient Israel from a biblical perspective in order to establish how modern societies grapple with questions of land and farming. Particular attention is paid to the Zimbabwean society in which the majority of rural communities - estimated to be $65 \%$ of the total population (Nsingo \& Kuye, 2005:745) - survives on subsistence farming. This kind of farming is traditionally known for providing livelihood for many households in Zimbabwe. This provides some revelation why land continues to be critical in Zimbabwe.

Since independence in 1980, Zimbabwe has been struggling to get her economy on an upward spiral. When the fast-track land redistribution programme (FTLRP) was introduced in Zimbabwe at the close of the 1990 s - in the process motivating land invasions -

The city of Uruk in southern Mesopotamia had close economic links to northern and eastern neighbouring regions. Sites in southern Anatolia, northwest Syria, and eastern Iran show the same material culture, architecture, and account devices as in Uruk. This city appears to have been the centre of administration for this complex system of trade and exchange, the largest and earliest urban settlement, with its impressively monumental public buildings and evidence of early bureaucracy. Largely, the success of Mesopotamian agriculture was its ability to produce enough surplus not only to feed the labouring masses but to free a large sector of the population from subsistence efforts. For more of these views, see Leick, G (2003). Historical Dictionary of Mesopotamia. Maryland: The Scarecrow Press, xvii. 
commercial farmers were evicted from commercial farming business. Numerous farm workers were left without jobs and income; others were killed and thousands of others assaulted (Human Rights Watch, 2002). FTLRP also instigated disorderliness in farming activities, and as a consequence, economic meltdown was experienced for over ten years. Even at the time of finalising this project in July 2017, industry is still paralysed, and many highly-educated and employable young people are roaming the streets daily without jobs and income. The only surviving employer for now is the Government. The country is currently being buttressed by the informal market, including vending. Revenue from the country's border posts constitutes the main portion of the country's overstretched budget.

In addition, both the The Financial Gazette, Daily News and The Standard newspapers have reported that it is a mammoth task to obtain funds from banks (see Mhlanga, 14 July 2016; Majaka, 05 April 2017; Sandu \& Mandizha, 09 April 2017). Government employees (and other bank card holders) can purchase food items among other things, only by using point of sale (POS) machines in supermarkets such as TM, OK, Metro, Peech \& Browne, Pick n Pay and Spar, among other established food outlets. It was established that to access cash, card holders sometimes use unorthodox means such as requesting a customer who wants pay cash to do so by using a bank card so that the card holder can get cash. Sometimes the card holder receives such a favour with a fee depending on the money received. Elsewhere, it is reported that POS machines are also being used at functions such as weddings (Tapfumaneyi, 31 Oct 2016). Many Zimbabwean citizens have been exposed to severe poverty. Even those who benefited from FTLRP are also enduring the acrimony of the economic meltdown. However, the revolutionary consciousness of solidarity, patriotism and indigenisation has fixated them to hold on to the view that FTLRP is a just cause.

This article thus intends to tussle with the problem of socio-economic development in Zimbabwe. Since agriculture is a dominant economic mode, the article will focus on issues of land and farming. While this is an economic issue that can better be dealt with from an economic point of view, I am convinced that a multi-disciplinary approach to one problem stands a better chance to deal with a given problem. For that reason, this article contributes to the discourse from an Old Testament (OT) point of view. In the OT, specifically during the post-exilic era, there is a scenario of reconstructing the economy after independence. Of importance for this article is the fact that the economy of post-exilic Judah was dominantly agricultural, similar to the Zimbabwean economy. This makes the post-exilic economic reconstruction relevant for what this study intends to do.

\section{Methodology}

Two critical methods are significant for the present essay. Firstly, this article will employ a method called hermeneutics of appropriation, by which means the article aims to identify biblical themes and to interpret them. Taking note of the contextual differences such as time, place, culture, etc., biblical themes will be appropriated in order to deduce lessons for the Zimbabwean situation. Charles Van Engen who has drawn such thoughts from the biblical text also maintains that God's covenant relationship with Israel was a contextualisation aimed at bringing light to the nations (Van Engen, 1991:102-103). In addition, the OT itself suggests that there are some constructive things that Israel could appropriate or learn from other religions (Goldingay \& Wright, 1991:34-52). It is also maintained that the OT emphatically affirms the oneness of humanity and that all peoples are under Yahweh's sovereign rule, even those under pagan viceroys (Talman, 1983:50). The above view is supported by the biblical and theological validity in which we find some 
ramifications emphasising that God's blessings and salvation are not intended just for Israel, but for all the nations of the earth (e.g. Psalms 67:2; See also Kärkkäinen, 2003:40).

Secondly, this essay will also explore post-exilic Judah with the help of secondary literature by other scholars. Since the overall discussion is premised on socio-economic reconstruction, the insights of Jesse Mugambi and Charles Villa-Vicencio on the theology of reconstruction in Africa will be roped in.

\section{The Covenant and the Land Question in the OT}

The book of Genesis blazes the trail by presenting the story of Abraham as an exodus from Ur to the Promised Land: "I am Yahweh who brought you out of Ur of the Chaldeans to give you this land to possess" (Gen. 15:7). As a fulfillment of the covenant which God made with Abraham (Gen. 12:1-3; 15:1-17; 17:1-21) Israel was given the land of Canaan (Hasel, 1983:193). This motif threads through the entire OT and in some parts of the New Testament. Noth (1960:111) has remarked that one of the original articles of Israel's faith was that it had once been "brought out of Egypt" by Yahweh (e.g. Exod. 20:2; Num. 23:22; 24:8; Deut. 26:5-9; Jos. 24:2-4; Judg. 6:13; 1 Sam. 4:8; 2 Sam. 7:23). Deut. 8:7-9 explicitly states Yahweh's command:

For the Lord your God is bringing you into a good land, a land with flowing streams, with springs and underground waters welling up in valleys and hills, a land of wheat and barley, of vines and fig trees and pomegranates, a land of olive trees and honey, a land where you may eat bread without scarcity, where you will lack nothing, a land whose stones are iron and from whose hills you may mine copper.

This connection of two journeys to the inheritance invites us to see moving on with God as a pattern of obedience (Van Seters, 1975:263). In both cases, there is a leaving in order to receive what is promised. Ancient Israel obviously cherished wonderful ideals about the Promised Land (Le Roux, 1992:141).

Amidst failures and harsh life experiences, the Israelite descendants still looked toward the future with hope for change for the better in their lives as a people in the God-given land of Canaan. They still imagined that Yahweh would lead them to some sovereignty in the unknown future, which Brueggemann (1985:2) refers to as prophetic imagination. In concurrence with Brueggemann's sentiments, Serfontein (2012:17) admits that images and imaginations of the future inspired and gave the Israelites hope in spite of harsh realities. The overarching editorial discourse of Genesis - the promise of eventually possessing the Land of Canaan - is issued by a deity to each new generation of the family. This means that the Israelites claimed the occupation of the land because the God of the Torah had made a covenant with their ancestors that counted as an inheritance for their generations to come. Thus at Shechem Yahweh had said to Abram: "To your offspring I will give this land" (Gen. 12:4-9), which is reaffirmed in Genesis 13:14-18.

Clements (1965:18) observes that the fact that the Israelite traditions located a number of incidents involving Yahweh and the people in the vicinity of the temple, points to its importance as the first home of the covenant people of Yahweh. This ideology of the covenant supports the notion that the deportation of the Judeans might have been narrated to portray the exiles as a covenant people, and this prompts the hypothesis that the narrative was written from the Diaspora elite perspective (Cataldo, 2009:71). The land question is also a topical issue in the postexilic literature. According to Jews in the Babylonian captivity the fulfilment of the covenant was to be realised on the land to which the exiles would return and where they would once again join in "the dance of the merrymakers" and 
worship in Zion (Raitt, 1977:402; Jeremiah 31:4-6). The exiles looked forward to a time in the unknown future when they would celebrate freedom after their experiences of distress, alienation and oppression in a foreign land (Rugwiji, 2013:4). We also see that postexilic biblical books are replete with teachings on reconciliation in connection with land. Malachi 1:5 idealises a peaceful life in Yehud and says: "My covenant was with him of life and peace..." (See also Mal 2:5). Malachi 2:16 mentions God hating a man for "covering himself with violence as well as with his garment." The above text expresses the view that Yahweh was opposed to violence among his 'chosen people.'

The postexilic Judean community was superimposed between two oppressive systems: on the one hand, the Persian Empire ${ }^{3}$ under which Judah had become a province, and on the other the Judean governors who exacerbated the suffering of the poor of society, from whom land, vineyards and houses were taken by the government. Although Ottuh (2013:260) has remarked that during the Persian period economic activities were booming among the Judeans, they were also in a precarious economic situation. When Ottuh admits that the society of Judeans was made up of the poor and the rich, he also clearly presents the notion that the latter took advantage of the former to exploit them. The poor constituted the widows, the orphans, the sick people and the destitute (Ottuh, 2013:260).

The land was visualised as a land of plenty, God's gift to Israel who should enjoy its fruits. Deuteronomy 8:7-8 and 11:11 express this view explicitly. The covenant made by Yahweh with the Israelite ancestors to occupy Canaan - a land situated between the Mediterranean Sea and the Jordan River, described as a good and spacious land, a land flowing with milk and honey (Exod. 3:8, 33:3; Deut. 31:20) - has enhanced our understanding of a people on a pilgrimage in search of both religious and political freedom. Some scholars say that this vision of "a broad, free land, a land flowing with milk and honey" supported the people through the wilderness, through war, mortal danger and famine (cf. Moltmann-Wendel, 1986:1). However, even after having settled in the Promised Land, the survival of the Israelites in the land flowing with milk and honey (Clements, 1968; Allegro, 1971:42; Leeming, 2004:23) was on numerous occasions threatened. During the postexilic period, land had similarly become a critical resource for survival. Fager (1987:60) has attested that during the Monarchic period land came to be viewed as a simple commodity and consequently accumulated in the hands of a few (see also Wenham, 1979:317; de Vaux, 1965:1, 72-73). The Jewish elders became corrupt by mortgaging land from desperate people who needed food to survive, contrary to the stipulations against such a practice in the book of Leviticus in which Yahweh had prohibited that: "... if you sell anything to your neighbour or buy from your neighbour's hand, you must not oppress one another" (Lev. 25:14), and "This land shall not be sold permanently, for the land is Mine; for you are strangers and sojourners with Me" (Lev. 25:23). In Yehud, such a practice was rampant. Nonetheless, Nehemiah challenged the Jewish governors who had mortgaged and expropriated from poor communities fields, vineyards and houses in exchange for grain in times of famine (Neh. 5:3).

This is evidence that the postexilic Judean community struggled to establish an identity for itself, even though they had anticipated an economic sustenance and availability of food in Yehud. Drought had struck the region so much that communities suffered a famine (Neh. 5:3). Added to that, the Judean governors who had been appointed by Persia to administer

This study attempts to present to the readership that Persia appears to have played two roles: (1) as a liberator and (2) as an oppressor. Although on the one hand Persia liberated the exiled Judeans and offered them some assistance towards rebuilding the temple, on the other hand, however, in administrative ways oppressed the Judeans. 
tax began to oppress the poor of the society; the leadership exacerbated the plight of poor communities by mortgaging their land, houses and vineyards as people struggled to pay tax due to economic hardship, and in the end, subjected their sons and daughters to enslavement (Neh. 5:5). This study shows that while it holds true that the Judean communities were oppressed by the Persians as explained above, to a large extent the Judeans became slaves to and were oppressed by their own Jewish brothers (5:6-8). Berlin (2005:65) has expressed it clearly that "exile does not necessarily mean living outside of the former kingdom of Judah. People living in the land of Israel after 538 BCE also felt that they were in exile as long as the temple was not rebuilt and even afterwards, as long as they were under the rule of foreign power." It is argued that the majority of Judeans were still living in Judah as supported by the depiction that the group which survived the deportation had to make claims to land rights (Ezek. 33:23-29), and that this group together with the priests were 'fasting' and 'mourning' in the fifth and seventh months throughout the exile (Zech. 7:1-7).

\section{Land and the Economic Situation in Yehud}

The economic situation in fifth-century Yehud is imperfectly known; therefore, the evidence must be viewed with caution (Miller 2010:5). However, economic survival is an overriding agenda of alienated and uprooted peoples who find themselves strangers and exiles in the land in which they live. Ottuh (2013:260) has revealed that the Babylonians captured the Israelites, destroyed the temple in Jerusalem and carted away valuables in 586 BCE. Economic exploitation was at the heart of the experience of the Judeans in the Babylonian exile. Vanderhooft (2000:6) explains that the Babylonian Empire focused on the domination and exploitation of non-Babylonian populations for the benefit of the ruling elite. Ottuh further affirms that when the Persians captured Babylonia in 539 BCE, the Jews were released from captivity and were given the freedom to worship their God and continue their economic activities in their land (See also Bean, 1991:1097; Frye, 1970:262). The negative situation in which the exiles found themselves does not mean the end of worship, but an emphasis of a different aspect of worship (Maré, 2010:121). The voice of faith now became the voice of tearful prayer (Mays, 1994:422). Tears are a result of inward emotional feeling of inadequacy, distress, anger, fear, crying and appealing for help. Sometimes crying empties the victim of the stress and the condition of misery resulting in tears.

The book of Lamentations explicitly relates to issues of sustenance such as templelessness and landlessness (Lam. 2:3-7; 4:9; 5:6). In the book of Ezekiel, it is noted that without land, and away from Yehud, the exiles saw themselves as 'dry bones' (Ezek. 4:14; 18:37). This supports the ramification that without land one is not only a virtual slave, but also a poor person. However, Persia having established itself as an authoritative administration in Yehud as one of its provinces meant subjecting the Judeans in a number of ways, including exploiting and usurping labour. Smith (1989:38-41) in agreement with Vanderhooft maintains that exploitation of the Judean exiles for their labour made them virtual slaves of the Persian Empire. Talking of the previous regime, the biblical text narrates that part of the ideology of subjugating the Judeans in Babylonia included some kind of 'cheap labour' provision as well as possibilities of other kinds of ill-treatment (Isa. 52:5; Jer. 51:6-7; Lam. 3:1-9; Psalms 137). The postexilic Judean community probably experienced the same treatment of oppression under the Persians (Neh. 9:36-37). This explains the economic challenges faced by Judean communities following the restoration.

The above observations are a direct contrast to the 'prophecies' in the postexilic literature. For example, the book of Zechariah, like Trito-Isaiah (56-66), envisioned 
restoration and good life, which was not yet realised, but which would definitely come in the land (e.g. Zech. 8:4-5, 12, 19; 9:15-17). It is further stated that the restored Judeans and their children would walk the streets of the city of Jerusalem. This would be a time of peace for Judah. People would live in the land until they were very old. Their children would be happy as they played (Zech. 8:4-5). Their land would produce grapes from which they would make wine, and the dew would provide water for sustenance (Zech. 8:12). People's fasts of the 4th, 5th, 7th and 10th months would be full of joy and happiness, and they would conduct happy festivals with love, truth and peace (Zech. 8:19). Yahweh would protect the Judeans and destroy their enemies. People would overcome enemy attack, and they would drink and make a noise like drunkards. They would be full like a bowl at the corners of the altar (Zech. 9:15). Yahweh would make his people safe, and they would shine in Yehud like jewels in a crown (Zech. 9:16). They would be attractive and beautiful, and the produce of the land (grain) would make the young men grow well, while new wine (from the grapes) would make the young women grow well too (Zech. 9:17). As Pleins (1993:41) concedes, even the anger of the refugee or the exile can become an act of prayerful worship. Israel's view of the "house of the Lord" appears to have been very strong during and after the exile. In the next section, we will examine the rebuilding of the temple for the spirituality associated with the divine.

\section{Rebuilding the Temple}

According to Ezra 5:16, the earliest attempt towards rebuilding the temple was begun by Sheshbazzar who first laid its foundation (539-525 BCE). Ezra 1:8 mentions Sheshbazzar as the prince of Judah, to whom the articles of the temple - which had been seized by Nebuchadnezzar from the temple - were handed by Mithredath the treasurer. Scheffler (2001:143) has pointed out that although Sheshbazzar and Shenazzar seem to be two different names in terms of spelling, Seshbazzar is believed to be the same as Shenazzar. Sheshbazzar was the head of delegation that returned to Jerusalem to restore the articles and rebuild the temple (Ezra 1:7). King Cyrus brought out the articles belonging to the temple of the Lord in Jerusalem which Nebuchadnezzar had carried away and placed in the temple of his god (Ezra 1:7). When the temple-reconstruction project was completed, the articles were returned to the Jerusalem temple. The rebuilding of the temple was central to the return of the exiles to the Promised Land. We have seen previously how the temple functioned for the administration of tax for the Persian Empire. For the Judeans themselves, the temple functioned for the reverence of Yahweh.

Adherents to the Torah or the Law comprised the majority of the pilgrims who converged to the temple at any given time and year to worship Yahweh. This institutionalising of the temple was the reason why most Israelites were unable to fulfil the requirements of the Torah away from home, because Yahweh was believed to avail himself and be accessed in the temple in Jerusalem. Yahweh was still known as a tribal God who exclusively demanded only Israel to worship him. The basic uniting factor in Yahweh's covenant with the patriarchs was the giving of land as inheritance and the allegiance of the Jewish descendants to worship Yahweh in the land, failure of which would result in disastrous consequences such as drought, war, invasion and deportation. Below, this article pays attention on the function of the temple in Yehud.

\section{The Function of the Temple}

The function of the temple in ancient Israel will also enlighten this discourse on the economic situation in Yehud. The temple played a central role in the lives of the Jewish 
communities. The fact that the Israelite traditions located a number of incidents involving Yahweh and the people in the vicinity of the temple, points to its importance as the first home of the covenant people of Yahweh (Clements, 1965:18). In certain psalms, the temple is presented as a place of refuge or asylum; a shelter against enemies and anyone dwells there in safety (De Vaux, 1965:161; Psalms 27:2-5); one is covered by the wings of Yahweh (Psalms 61:4-5); but the wicked are not allowed in (Psalms 5:5). The temple is specifically associated with sedentary life (Gray, 1964:69). The destruction of the temple and the termination of the Davidic dynasty had a profound influence on the people's thinking, because they had expected the continuity of the Davidic dynasty (2 Sam. 7:4-17). It is probable that the Jews who had remained when others were taken in captivity, still gathered in some place - perhaps at the destroyed temple area - to worship Yahweh. The emphasis on Jerusalem as a city which should not be forgotten depicts its significance because of the temple that was located there (Psalms 137). The temple was regarded as the chief place of God's presence on earth and as an earthly representation of his heavenly abode, and most likely, the place to where he would descend (Schader, 2010:147). It is significant that in the psalms Israel's possession of land is related to Yahweh's abode on Mount Zion (Clements, 1965:52). It was to these ends especially that the temple cult was directed, and the presence of Yahweh on his holy mountain was thought to be a firm assurance that his goodness and kindness would continue to be with Israel (Clements, 1965:76). The temple was further attributed with the function of being a place where Yahweh would unite people, as Ringgren (1963:23) points out: "the cult ... especially in its most elaborate expression in the Jerusalem temple, served as a unifying influence within the nation, creating a sense of nationhood and oneness, which, without it, would have been lacking." However, this 'nationhood' and 'oneness' was viewed by Ezra as of 'little sustenance' (Ezra 9:8), implying that Ezra was not certain whether they would be really free in Yehud.

The concept of the "house of the Lord" may have received an extended interpretation as indicative of "the household of faith" (Isa 56:7; 60:7; Hag. 2:7), that is, the company of all loyal worshippers of the Lord as God (Johnson, 1970:255-271). This servitude is cemented by a language of praise, as depicted by most of the psalms. To the Judeans, these praises reinforced the truth about Yahweh. Yet they clung to God and his promises for deliverance. The temple also functioned as a centre for collecting tax for the Persian administration. The next section explores tax-collection in Yehud.

\section{The Temple and Collection of Tax}

We get the glimpse that when Yehud had become a province of Persia, the temple was also used as a centre for tax-collection for Persia. As admitted by Purvis (1999:178) the Persians had demanded both political loyalty and the payment of taxes. Schaper (1995:528) also remarks that a few passages exist in postexilic biblical texts which give us an insight into the Jerusalem temple as an instrument of the Persian administration. Neo-Babylonian kings seemed to have demanded temple-tax from the Judeans, and when the Persian Empire took control of Judah as one of its provinces, a requirement for temple-tax remained in force. The main income of the Babylonian temples was generated by the tithe, which was payable either in precious metals or in kind (Schaper, 1995:528). In addition, Dandamaev and Lukonin (1989:361-362) have confirmed that "the tithe was paid in the majority of cases in barley and dates, but also frequently in silver, emmer, sesame, wool, clothing, small livestock, cattle, poultry, fish, etc. The tithe corresponded to a tenth of the incomes of taxpayers." The book of Zechariah also throws light on the practice of temple-tax in Jerusalem. 
Torrey's description is indicative of the practice of temple-tax collection prevailing within the Persian Empire, which illustrates that the temple functioned as a storehouse for the safekeeping of treasures such as gold and silver. Grabbe (2000:33) concurs that the Persians may well have used existing structures, including temples to collect taxes. This is confirmed by Schaper (1995:528) who mentions that the Achaemenids took over from the neo-Babylonian kings the concept of a mandatory temple tax or tithe. The book of Nehemiah also confirms that the temple functioned as a storehouse where it stipulates that: "For the people of Israel and the sons of Levi shall bring the contribution of grain, wine, and oil to the storerooms where the vessels of the sanctuary are, and where the priests that minister, and the gatekeepers and the singers are. We will not neglect the house of our God" (Neh. 10:39).

This requirement mentioned by Nehemiah above was a kind of tax known as teruma in Hebrew (also known as midda in Aramaic), which was stored in the temple treasury (Schaper, 1995:536). In the same vein, Eph'al (1988:158-159) notes that midda or minda was a 'tribute tax' paid to the king personally, while belo was a 'poll tax' and the halak was a 'land tax,' respectively. The above passage in Nehemiah explains further that besides providing storage of precious metals such as silver and gold, the temple also served as a storehouse of food reserves needed either for future use, for helping the needy or for the care of temple employees such as priests. Still, the key role played by the temple was administering taxes for the Persian Empire.

The book of Ezra also provides evidence of a tax described as tribute paid by the Judeans to Persia where it reads that: "Jerusalem has had mighty kings who ruled over the whole province Beyond the River, to whom tribute, custom, and toll were paid" (Ezra 4:20; 7:24). The same notion is also clearly depicted in the book of Nehemiah when people complained to Nehemiah about payment of tax: "And there were those who said, 'We have to borrow money on our fields and vineyards to pay the king's tax" (Neh. 5:4). This essay will now examine the function of the deity in influencing economic stability or lack of it in ANE.

\section{The Land, the Deity and Economic Sustenance}

In the ANE a nation's economic prosperity or lack of it in the land was attributed to God or gods (e.g. Yahweh; see Ezra 9:5-9; Hag. 1:1-11). The erection of a shrine and the establishment of a cult for the divine was a motivation for a blessing and a national economic boom initiated by a Supreme Being. The economic stability of a nation was explained in terms of people's allegiance to the cult. Neglect of these would result in curses and or deportation. The cult was believed to be attached to the land and sometimes to the moon. The Supreme Being who gave land to the people to inhabit would provide the rains from the moon god for the people to reap harvest. In that sense, if the cult was dishonoured, the result would be famine in the land because the gods had been angered and had therefore brought curses (e.g., famine, sickness, oppression, exile, etc.) instead of blessings. As for the Jews, Yahweh would inflict curses if they sinned or deviated from him. Their misfortune was punishment for their sins (Spangenberg, 1992:305). The following examples will shed more light.

Job 4:7 portrays that the upright and the innocent do not suffer, suggesting that Yahweh was punishing Job for sinning; Haggai 1:9-11 depicts that the Judeans suffered famine as a result of drought because they had neglected building the temple for Yahweh; Malachi 3:1 states that the Judeans remained cursed and would not prosper as long as they despised paying tithes into the temple treasury; Yahweh had scattered the Israelites among the 
nations for being unfaithful (Neh. 1:8-9); according to Ezra 9:5-9 the Babylonian captivity occurred because the sins of the Judeans were "higher than our heads and our guilt has reached the heavens" (Neh. 9:6). Further still, the book of Ezra portrays Cyrus as a one who believed in Yahweh, which the author expresses in the following passage: "Thus says King Cyrus of Persia, "The Lord, the God of heaven, has given me all the kingdoms of the earth, and he has charged me to build him a house at Jerusalem in Judah" (Ezra 1:2). This portrayal is contradicted by Isaiah 45:4-5 which says: "For the sake of my servant Jacob, and Israel my chosen, I call you by your name; I surname you, though you do not know me. I am the Lord, and there is no other; besides me there is no god. I arm you, though you do not know me." Based on these verses, a number of scholars have suggested that Cyrus like many other kings in ANE - believed in many gods (Yamauchi, 1980:200). Others suppose that Cyrus was an adherent of Zoroastrian teachings; yet Zoroastrianism was monotheistic in character.

Presuming Cyrus to be a polytheist, he might have been a reader of Hebraic biblical teachings after which he concluded that Isaiah 45 referred to him, even though he did not particularly believe in Yahwism. Cyrus' belief in other gods (and not Yahweh) is substantiated by both James Pritchard and Amelie Kuhrt who provide detailed accounts of the clay cylinder (called the Cyrus Cylinder) on which Cyrus gave credit to the local god Marduk for enabling him to capture Babylonia (Pritchard, 1954:206-208; Kuhrt, 1983: 83-97). In addition, Cyrus encouraged his subjects to worship other gods such as Bel and Nebo (Pritchard, 1954:208).

The Jews themselves might also have believed that, although Yahweh was their God, other gods existed also, to whom they would turn for divine intervention. The book of Jeremiah narrates that when Jeremiah preached to the Judeans who lived in Egypt to return to Yahweh who was punishing them for their deviation (Jer. 44:13), they protested that they were not going to listen to Jeremiah (44:16). Instead, they responded: We will do everything that we have vowed, make offerings to the queen of heaven and pour out libations to her, just as we and our ancestors, our kings and our officials, used to do in the towns of Judah and in the streets of Jerusalem. We used to have plenty of food, and prospered, and saw no misfortune (Jer. 44:17).

The above revelation portrays the view that Judean ancestors were used to worshipping the queen of heaven, and not Yahweh, who referred to himself as: "I am who I am" (Exod. 3:14), when he first introduced himself to Moses at Mount Sinai. The Judeans in Egypt believed that the queen of heaven was angered because they had neglected honouring her, hence their suffering and exile. The returned Judeans in Yehud might have carried this notion when they regarded the prevalence of drought in the land as a result of punishment by Yahweh for disobeying him (Hag. 1:4-11). Israel might have regarded Yahweh as having a specific place of abode. This is also made clear by what we read in the last part of Ezra 1:3, which reads: "...the God who is in Jerusalem." We have already seen that Cyrus believed in other gods, but the Judeans would give reverence to "the one in Jerusalem." Regardless of Cyrus not recognising Yahweh which many Judeans did, Yahweh chose Cyrus (a pagan) to liberate the Judeans from captivity in Babylonia. The message dominant in Haggai's oracles is the consequence for neglecting to rebuild the 'Lord's house' (Haggai 1:2), and these consequences included economic decline, invasion, and plagues, among others. Hanson (1987:495) has affirmed that the admonition in Haggai to 'build the house' carries a twin mandate: (1) give proper glory to God and (2) restore the economic system of the land. 
It follows that from the beginning of Israel's sojourn, the success, development, protection, liberty, sovereignty, sustenance and peace in the land among the Judeans depended largely on their continued interaction and obedience to the law and the demands of Yahweh (Ezra 9:5-9). In the book of Haggai, we read about people having built for themselves 'panelled houses' (Hag. 1:4), an indication that to some extent, Judah was experiencing some form of economic reform. Haggai's description suggests that these were no ordinary houses; they were 'panelled,' perhaps showing some 'beauty' and that much time and resources were spent in erecting such structures. Haggai is implicit to describe people's attitude as simply an act of neglect. After all, this "building of panelled houses" was being done against the backdrop of negligence to rebuild the temple, Yahweh's dwelling place. Haggai 1:4-11 conveys the idea that this neglect resulted in Yahweh inflicting curses on them such as little harvest, having insufficient food and drink, and lack of warm clothes. Even if they earned wages, it would not sustain them, as if to say they were not paid. The exile, enslavement, famine and poverty that affected people, were all believed to be consequences of neglecting the "house of God" (2 Chr. 36:10-21; Neh. 1:410, 5:1-5; 9:3-37; Ezra 9:5-9). The abundance of mineral resources, metals and circulation of coin money sustained the economy in Yehud. Next, we look at these themes.

\section{Minerals, Metals and Coin Money}

Coin money was critical in trade and commercial activities in Yehud. Archaeological discoveries of coins provide evidence that these were used as mode of trade and for commercial transactions. These coins were probably used for everyday business activities as well as for bilateral economic exchange across the Persian Empire and beyond. Kanael (1963:39) comments that coined money rapidly became common throughout the ancient world... The Persians also started to issue gold and silver coins. Kanael further asserts that the first coins mentioned in the Bible were Persian ones, citing Ezra 2:69, which reads: "According to their ability they gave to the treasury of the work sixty-one thousand darics of gold..." It is further chronicled that in Judea, Persian coins were current, on which the effigy of the Persian king appeared(Kanael, 1963:40).

In Yehud, mineral resources (such as metal, iron, copper, gold, silver, etc.) were in abundance as evidenced by smelting tasks which were undertaken. In Zechariah 11:13 we also read: "Throw it into the treasury - this lordly price at which I was valued by them. So I took the thirty shekels of silver and threw them into the house of the Lord, to the potter." Torrey (1936:258) translates the term yoser (potter; Zech. 11:13) as caster or founder, which he says "denotes a minor official of the temple whose task was to melt down silver." In addition, Ezekiel's annunciation that: "As silver is melted in a smelter, so you shall be melted in it, and you shall know that I, the Lord, have poured out my wrath upon you" (Ezek. 22:22), was an expression of what was common in ancient Israel. Torrey (1936:247) further says that one of the features of Zerubbabel's temple was a foundry, in which the precious metal given to the treasury was melted down. If "melting down silver" was practiced in Yehud, it depicts that technology was at an advanced stage and probably existed before the exile. Schaper (1995:532) concurs that there had been a foundry at the Jerusalem temple even before the exile, but it was reintroduced and capitalized by the imperial administration for the purpose of exploiting the local natural resources for its upkeep. Torrey (1943:298) further explains how precious metals were stored in the temple chambers. In the centuries before $300 \mathrm{BCE}$, while coin money was little known or scarce in Palestine, and also decreasing in the later time, the precious metal which was brought to the temple as regular revenue or votive offering, came in the form of lumps, fragments, utensils 
and trinkets of every description and shape. There are also illuminating glimpses that gold and silver were given to the treasurer towards the rebuilding project:

The Tirshatha gave to treasure a thousand drams of gold, fifty basons, five hundred and thirty priests' garments. And some of the chiefs of the fathers gave to the treasure of the work twenty thousand drams of gold and twenty thousand and two hundred pounds of silver. And that which the rest of the people gave was twenty thousand drams of gold, and two thousand pounds of silver, and threescore and seven priests' garments (Nehemiah 7:70-72).

\section{Sabbath, Business and Trade}

The Sabbath was set aside "unto the Lord thy God" (Exodus 20:10), and proclaimed the coming era of rest. The law and the prophets called upon all Israel to keep the Sabbath (Exod. 20:8-11; 31:14; 34:21; Lev. 25:2; Deut. 5:12-15; Amos 8:5; Jer. 17:21; Ezek. 20:1224), as an essential requirement of worship during and after the exile (Isa. 56:2, 6; 58:13). Nehemiah was concerned about Sabbath observance (Neh. 10:31). It was disregard for the Sabbath that had brought upon Israel the judgment of the exile (Holmgren, 1987:152). Nehemiah 13:16 shows that Tyre had established a trade in Jerusalem to conduct business in fish and other merchandise (Blenkinsopp, 1988:359-360; Myers, 1965:213; Williamson, 1985:395). It is further affirmed that trade in various products existed between Tyre and Judah, and that business would be conducted even on the Sabbath. God's wrath would come upon the restored community if it continued to allow the buying and selling of goods on the Sabbath day (Jer. 17:27; Ezek. 20:23-24). In his show of adherence to this prohibition, Nehemiah made arrangements that kept all traders well away from Jerusalem on the Sabbath (Ashton, 1992:164). Nehemiah appointed Levites to guard the gates on the Sabbath to prevent any repetition of the problem (Neh. 13:22). Together with tax-collection in Persian-controlled Yehud, commercial activities sustained the economic life of the Empire.

\section{Breeding of Livestock in Yehud}

The biblical text also presents the offering of sacrifice as an important practice which Yahweh demanded of his people. The concept of atonement (an offering for sin) has been interpreted as evoking the image of the scapegoat (Motyer, 1999:381-382). Sacrifice involved killing an animal (usually a sheep/goat) as a sin offering to Yahweh (Lev. 16:2021). Scheffler (2001:136) also admits that although the temple was in ruins and not rebuilt during the exilic period, it must be assumed that the worship of Yahweh continued, and that sacrifices were made (probably on the temple site; see Jer. 41:4-6). After the rebuilding of the temple, sacrifices were made to Yahweh. These included: one hundred bullocks, two hundred rams, four hundred lambs, twelve he-goats (Ezra 6:17). After the completion of rebuilding the walls by Nehemiah, the returning Judean exiles had brought with them "their horses, seven hundred thirty and six; their mules, two hundred forty and five; their camels, four hundred thirty and five; six thousand seven hundred and twenty asses" (Neh. 7:67-69).

Having discussed land, farming and agriculture in Yehud, this study now examines the above themes in our post-biblical world in order to demonstrate that modern ways of life compliment ancient Israelite cultures and practices in many ways as part of the 'human 
nature ${ }^{4}$. In order to achieve that, this project utilizes a theology of reconstruction explored below.

\section{Theology of Reconstruction}

The idea of theology of reconstruction which was propagated by scholars such as Charles Villa-Vicencio (1992), Tinyiko Maluleke (1994) and Jesse Mugambi (1995) respectively which was further problematized by Elelwani Farisani (2002) - is paramount as we grapple with the debate on rebuilding Zimbabwe. The Judeans had returned to Judah. The anxiety of being away from home in a foreign land was in the past; the passion to determine their own future and their destiny was now unfolding. Now was the time to focus on developing their own lives and rebuilding their homes and other infrastructure. When Villa-Vicencio and Mugambi read the above themes in the narratives about the postexilic Judean community, they proposed a theology of reconstruction for the modern postbiblical world. In his book, Villa-Vicencio explores the perils intrinsic to linking theology and nationbuilding, particularly the tendency for theological thinking to deteriorate into the theological legitimation of national ideology. In addition, Mugambi's contribution shifts from the liberation-enculturation paradigm which was mainly reactive to developing a proactive theology of reconstruction (1995:11-13). Mugambi has further maintained that thinking about the liberation phase (e.g. the exodus liberation motif/the Babylonian exile) was not necessary; what was necessary was rebuilding their land and restoring their dignity as a people.

A theology of reconstruction could in some way be defined as a theology of rebuilding in contrast to liberation theology or theology of liberation, to which Mwaura (2010:131) refers as a process of post-conflict reconstruction. By theology of rebuilding Mwaura suggests that after liberation has been achieved, what follows is the task of dealing with societal issues beyond the conflict. It is an exercise towards development that government and local communities begin to embark on at the end of a conflict. The concept of postconflict refers to the period following the end of a conflict in a given country (Nkurunziza, 2008:4). It could also be referred to as a post-conflict reconstruction. Theology of liberation is the initial phase of a long process of self-emancipation from oppression. It attempts to fight for justice from colonial or imperial forces. The liberation motif of the exodus, however, is not enough. A liberated society needs to refocus attention on rebuilding the nation that has been ravaged by political conflict. Quite often, the nation-rebuilding programme entails integrating and working together with those who were previously fighting each other. In concurrence with both Mwaura and Nkurunziza, Waskow (1990:518) has also remarked that in the liberation of the Israelites from slavery in Egypt, there is no reconciliation. In view of Waskow's observation, one would conclude that liberation theology of the exodus remains the initial phase of an unfinished business, a work in progress. The restoration of the Judeans from Babylonia back to Judah was one grand achievement. However, patterns of everyday life in Yehud and the sustenance of peace and order for economic transformation to prevail was another task which needed to be reworked. It is for this reason that Jesse Mugambi and others have proposed a theology of reconstruction which focuses on rebuilding as well as reconciliation in the postindependence era after freedom has been achieved. The above view is also echoed by Gathogo (2009:100) who has reaffirmed what Mugambi (1995:160-180) proposed, that the

4 The interesting idea of the 'human nature' was borrowed from Robert C Ellickson and Charles Dia Thorland (1995)'s Ancient Law: Mesopotamia, Egypt, Israel. Paper 410:328. 
figure of Nehemiah, unlike that of Moses, gives us the mirror through which we are able to spot out our mission to remake Africa out of all sorts of ruins that continue to bedevil it.

After his A Theology of Reconstruction: Nation-Building And Human rights (1992), in his other work titled: From Liberation to Reconstruction, Mugambi (1995:18) asserts that the New World Order poses a challenge inviting us to be very creative and innovative. This new world order, in my view, is the era of change. Heyns (1992) subscribes to this notion of change by affirming that change brings an awareness of the passage of time of a world that does not remain the same. Heyns further notes that change leads us to face the reality of time, the reality of the unknown and unpredictable future. In another sense, Mugambi suggests that Africa should redefine and reconstruct her own future, so that the Africa of the 21 st century will have to pre-occupy itself with the agenda of reconstruction as the new priority, The text of Ezra-Nehemiah, unlike that of the Exodus, has to be the main text in the explication of African theological discourses in the 21 st century. This text will motivate the people of Africa to rebuild their continent from all sorts of ruins. Reconstruction is the new priority for African nations in the 1990s (and beyond). Mugambi (1991:36) states that the churches and their theologians will need to respond to this new priority in relevant fashion, in order to facilitate this process of reconstruction, since it will require considerable efforts of reconciliation and confidence-building.

In sum, Mugambi advocates for a theology of reconstruction based on the process of social reconstruction which invites every member of society to participate in establishing a new social order more aligned with God's intention for humanity (Mugambi, 2010:139). Mugambi's appropriation of Ezra-Nehemiah's reconstruction theology to the modern postcolonial crisis in Africa is also echoed in Charles Villa-Vicencio's contribution. The latter's works include: A Theology of Reconstruction: Nation-building and Human Rights (1992). Villa-Vicencio holds that a theology of reconstruction is one way of social renewal. With particular reference to Villa-Vicencio book (1992), Sarah Stephens (1994) speaks highly of Villa-Vicencio whom she describes as someone who has "...long been respected as one of the incisive theological voices of the anti-apartheid struggle in South Africa." Although Mugambi mentions Ezra-Nehemiah, he does not refer to a particular text.

Villa-Vicencio propounds a shift from liberation theology to the theology of reconstruction as a movement from the past to the present; from one phase of the struggle to another. This last phase hinges on economic emancipation, that is, provision of food. In this sense, Villa-Vicencio could not be far from understanding the society of Nehemiah's time which cried out: “...We and our sons and daughters are numerous, in order for us to eat and stay alive, we must get grain" (Neh. 5:2). From Villa-Vicencio, I focus my attention on Tinyiko Maluleke's contribution and how he appropriates the postexilic Judean context for the modern postcolonial/apartheid situation.

Maluleke (1997:22) comments that Villa-Vicencio appeals for a post-cold war (African) theology to engage in serious dialogue with democracy, human rights, law-making, nationbuilding, and economics in order to ensure that these do indeed improve the quality of human lives. Although Maluleke is well-known as one of the faithful champions of Black Theology (Farisani, 2010:508; Maluleke, 1996a:3-19) his recent line of thought has been a reflection of his previous discourses in dialogue with the recently-introduced theology of reconstruction and how his traditional trademark has been influenced by both VillaVicencio's and Mugambi's theologies of reconstruction. On the one hand, Maluleke attempts to harmonize his Black Theology with reconstruction theology. In support of Mugambi, Maluleke (1996b:473) spoke highly of him whom he described as "a passionate and committed African Churchman, theologian and continental patriot of our times." At 
this point, Maluleke does not depart from either Mugambi's or Villa-Vicencio's views where he acknowledges that "reconstruction, development, and democracy are fast becoming as integral to South African political language as the notions of the struggle, revolution and liberation used to be" (1994:245).

On the other hand, Maluleke (1997:23) has been critical of both Mugambi and VillaVicencio in their assumption that the end of the cold war has immediate significance for ordinary Africans and that the so-called New World Order is truly new and truly orderly for Africans. Maluleke argues further that the New World Order is not only likely to relegate Africa into a 'fourth' world but it will also impose its own prescriptions on African countries. In addition, Maluleke criticizes both Mugambi and Villa-Vicencio for what he describes as "minimizing the value of previous African theologies of enculturation and liberation," electing to maintain what he calls a 'liberation paradigm' (Maluleke, 1996:473; 1994:245-258). Why Maluleke chooses to differentiate theologies of 'enculturation and liberation' from 'reconstruction theology' instead of 'marrying' the two, appears to me, his reluctance to accept that a new world order has come and so change is inevitable.

Elelwani Farisani does not present his case differently from either Villa-Vicencio, Mugambi or Maluleke. In his doctoral thesis, however, on the title The Use of EzraNehemiah in a Quest for Theology of Renewal, Transformation and Reconstruction in the (South) African Context (2002), Farisani disagrees with both Villa-Vicencio and Mugambi whom he critiques as being biased against the am haaretz (the people who remained the land when other Jews were taken to captivity in Babylonia). For Farisani there existed a conflict between the returnees and the am haaretz (2002:127), particularly in the case in which the latter were disallowed to take part in the rebuilding (reconstruction) programme. Farisani's argument complements in a unique way the contestations raised in this particular study in which inclusion and exclusion ideologies are explored. On the one hand, this study does not seek to be sympathetic to either Farisani's stance or members of society who regard themselves as excluded or prejudiced because they belong to a certain category of the populace (for example, poor, uncivilized, black, white, anti-revolutionary, or ethnic race differences). On the other hand, history seems to repeat itself. Facets or layers of exclusion and inclusion in our postcolonial context have recently emerged as the modus operandi particularly among revolutionary individuals overwhelmed by fear to withstand challenge. This study discusses theology of reconstruction in the Zimbabwean context in view of celebrated liberation claimants who tend to marginalize those who do not have liberation credentials.

\section{Theology of Reconstruction in Zimbabwe}

Robert Mugabe became Prime Minister of postcolonial Zimbabwe in April 1980. During the first 10 years into independence, Zimbabwe was a prosperous country by African standards, in part because of a large commercial farming sector run by white farmers, many of whom were Zimbabwean citizens (Howard-Hassmann, 2010:890). Towards the end of the 1990s, land redistribution (particularly land invasion) has been at the centre of controversy in Zimbabwe, which caused the economic meltdown. David Coltart concurs that "Mugabe and his cronies are chiefly responsible for an economic meltdown that has turned one of Africa's most prosperous countries into a country with one of the lowest life expectancies in the world" (2008:1). Although some critics have argued that SED of Zimbabwe has not been successful since the postcolonial state elite took power in 1980 (cf. Maundeni, 2004:189), this notion is debated by some who hold that the postcolonial Zimbabwean government had scored remarkable socioeconomic successes a few years into 
independence. However, the transfer of all land owned by white commercial farmers to the black people (Ndlovu-Gatsheni, 2009:1140) has been criticized as the cause for the economic meltdown experienced in Zimbabwe. Many people who were opposed to the manner in which the programme was executed, still believe that a decade that followed after the first phase of compulsorily acquiring land in 1999, plunged the country into severe economic crisis. Zimbabwe is an agro-economy, and the bulk of its Gross Domestic Product (GDP) derives largely from the production of crops such as: tobacco, maize, wheat, soya beans, potatoes and many others.

Land redistribution in its entirety is not widely disputed among the majority of Zimbabwean citizens. It is the political violence associated with it which is highly protested. Since the formation of the Movement for Democratic Change (MDC) in September 1999, as well as ZANU (PF)'s narrow victory in the following elections which the MDC contested, Mugabe's revolutionary machinery was deployed to torture, subject, marginalise, oppress and exploit his own black people believed to be the enemies of the state, and suspected of having Western connections and/or allies through MDC (Rugwiji, 2013:32). It was under these circumstances that white commercial farmers in Zimbabwe lost their farms through the infamous land invasions instigated by Mugabe's ZANU (PF) government. Kriger (2003:407) chronicled that the guerrilla veterans of the Zimbabwe liberation war played a prominent role in intimidating members of the opposition MDC and in spearheading the invasions that drove white farmers from the land and led to the chaotic fast-track landdistribution reform exercise, popularly known as the Third Chimurenga (Rugwiji, 2013:32). Compagnon (2011) has equally argued that the current Zimbabwean crisis is a predictable and logical consequence of the character and policies of Robert Mugabe since independence. Compagnon's observation confirms my own argument that Mugabe's character was always violent and militant from the beginning, that he had always believed in the war and armed struggle to bring freedom to the Zimbabwean people (Rugwiji, 2008:137).

There is need to focus on rebuilding Zimbabwe in view of theology of reconstruction. The following sections will attempt to discuss strategies towards reconstructing Zimbabwe for the country to revert to its past heydays as the breadbasket of Africa

\section{Review of Land Reform}

The government is currently at liberty to repossess commercial farms from individual Cabinet Ministers, Members of Parliament, and managers of institutions, who lack both the expertise and the commitment to run a farming business; proof of the latter lies in the fact that, during the time such an occupant occupied the farm, no farming activities were taking place. Where no individuals are found to be capable of running a farm for commercial purposes, the government may revolutionise its agricultural training institutions by training qualified individuals, starting with an intensive six-months training period, which will be reviewed after the first batch of graduate farmers.

I have already alluded to the fact that subsistence farming is traditionally known for providing livelihood for many households in Zimbabwe. The main crops are: chibage (maize, from which they grind maize-meal that is used for making sadza - thick porridge), nzungu (groundnuts), nyimo (round nuts), mbambaira (sweet potatoes), manhanga (pumpkins), muboora (pumpkin leaves, which are eaten with sadza), and nyemba (kind of beans, which can be boiled together with maize grains). Besides using some of their yield for household purposes, subsistence farmers also sell their surplus to the market in order to buy other foodstuffs such as salt, bread, sugar, and vegetable oil. Those who live in city 
suburbs also use the under-utilised space in the backyard for cultivating crops (technically described as peri-urban farming), such as vegetables, maize or potatoes. However, this practice is being discouraged by city councils, because robbers might use such patches as hideouts. Zimbabweans are also known for rearing or breeding animals, such as: cattle (from which they get fresh milk), goat, sheep, rabbits, pigs, and chickens. In times of crisis, they might sell some of the beasts to pay for school fees or roora (lobola), among other things. It follows that without land and animals such as cattle or goats one is rendered and considered poor. This provides some revelation why land continues to be critical in Zimbabwe. The importance attached to agriculture in Zimbabwe is reflected by the government's commitment to establish the following four related ministries which are complementary in character:

- Ministry of Agriculture, Mechanisation and Irrigation Development (formerly, Ministry of Lands, Resettlement and Rural Development),

- Ministry of Agriculture Parastatals,

- Ministry of State, Land Reform and Resettlement, and

- Ministry of Water Resources and Infrastructural Development.

Mangena (2009:78) has observed that although the colonisers seized Zimbabwe's land somewhat fraudulently, the ZANU (PF) government, in an effort to correct these historical imbalances, should simply have followed just and democratic processes in the redistribution of land, rather than using force and violence against a relic of the white commercial farmers. Mangena further lamented that two wrongs do not make a right. The land invasions impacted negatively on agricultural productivity in Zimbabwe.

\section{Need for Orderly Resettlement}

Following the compulsory land acquisition in the late 1990s, agriculture has struggled to regain the status it enjoyed during the early 1980s. Many people have raised concerns that the controversial land reform exercise or land redistribution programme has contributed a great deal to the downturn of the Zimbabwean economy, as well as a decline in tourism (Rugwiji 2012:148). As a result of the land invasions, the farming sector suffered numerous pitfalls. White commercial farmers who were dispossessed of their farms opted to move both their human and material resources to neighbouring countries such as Zambia, Mozambique and South Africa. Soares Nhaca, the governor of the central Mozambican province of Manica, confirmed: "The Zimbabwean farmers with about 1000ha of land each have so far generated a total of 4118 new jobs" (The Star, 14 Jan 2004). This brings into question the genuineness of the solidarity some African countries were believed to have towards Zimbabwe's land policy. This is further proved by Mkodzongi (2011:346) who likewise reports that some countries, while outwardly supporting Zimbabwe's fast-track model. were beneficiaries of "foreign direct investment" after offering evicted Zimbabwean commercial farmers incentives to invest in their respective countries. The above revelations have exposed the double standards and insincerity exhibited by African heads of state whom President Mugabe still held in high esteem as supporting the land reform in Zimbabwe. The fact that the same countries went ahead to welcome and accommodate white farmers who left the country after they were evicted from their farms in Zimbabwe explains that they have no agenda for land reform in their respective countries. Yet the same countries pretend to speak highly of Mugabe as a hero for evicting commercial farmers in Zimbabwe's controversial land reform. Meanwhile, having lost commercial farming business, Zimbabwe was soon heading for a collision course - politics versus the 
economy - which resultantly destroyed the country's reputation of being the granary of Southern Africa (Nürnberger, 2003:504). In addition, Moore (2005) aptly notes that once the bread basket of southern Africa and a major agricultural exporter, Zimbabwe now depends on food programmes and support from outside to feed its population. This calls for sanity on the part of leadership in Zimbabwe for sustainable development to recur in the country. The resuscitation of SED can be done by way of reviewing the land reform as alluded to above, as well as reviewing the country's foreign policy in terms of legislation on investment, ownership of business shares and allocation of profits.

\section{Imitating Nehemiah's Example}

In Zimbabwe, there is need for the leadership to be exemplary by imitating the biblical Nehemiah. Neither Nehemiah nor the members of his household had acquired land. It appears Nehemiah did lend money and grain (Neh. 5:10): "I and my brothers and my men are also lending the people money and grain", but he did not exact usury. As one of the governors of the Persian Empire, Nehemiah had food allocated to him, as evidenced by his statement that "...neither I nor my brothers ate the food allotted to the governor" (Neh. $5: 14)$. The previous governors were not only greedy and selfish by keeping the food they received from the government, they also demanded from the people "forty shekels of silver $\ldots$ in addition to food and wine" (Neh. 5:15). This further worsened the plight of the communities. While all the other governors were busy scrambling for food and other material resources from the government at the expense of the poor, Nehemiah, in contrast, devoted himself to rebuilding the walls (Neh. 5:16). In Nehemiah's statement that "we did not acquire land" (Neh. 5:16), the "we' seems to refer to himself and his brothers. It appears that all other government officials had acquired land for themselves, while they also repossessed the land that belonged to the poor, which was the latter's only source of livelihood (5:5). Clearly, the more resources the governors had, the more their greed intensified. Nehemiah turned his homestead or government house where he probably stayed, into a rendezvous where he fed "a hundred and fifty Jews and officials...as well as those who came to us from the surrounding nations" (Neh. 5:17). The food that was prepared for him each day, Nehemiah gave to members of the community, and included oxen, sheep, and poultry. Every ten days Nehemiah had a ration of "an abundant supply of wine of all kinds" (Neh. 5:18). This portrays Nehemiah as a leader committed to alleviating poverty in the community. However, Nehemiah was the opposite of the nobles and officials among the Judeans. He invited members of the community to come and eat at his homestead (Neh. 5:17) and gave people food every day with a clear conscience, knowing that their "demands were heavy" (Neh. 5:18). Now that Nehemiah had rebuked the nobles and officials to cease their usury and to return the vineyards and homes to the rightful owners (the poor peasant farmers), and perhaps follow his example of providing food, the deprived farm communities would begin looking into the future with hope.

In Zimbabwe, poverty has been a subject of concern among most communities. When Kunhiyop (2008:138) remarked: "From the tip of the horn of Africa to Namibia, poverty is pervasive...," his analysis included Zimbabwe. Although the majority of Zimbabweans is generally known to be poor, the state of poverty has been exacerbated by the dynamics of politics since 2000. In the past, Zimbabwe has been known to exist through prioritisation of unjust 'operations' as its norm. These operations are given code-names, for example, the ethnic insurgency of the early 1980s in Matebeleland province: Gukurahundi (Rugwiji, 2012:233), the clean-up exercise of 2005: Operation Murambatsvina (Saunders, 2011:126), and the FTLRP: Third Chimurenga (ZHRNF, 2010:11). All these operations are 
characterised by injustice (Mamdani, 1991), violence, intimidation, assault, and murder of citizens, especially civilians. Although on closer examination these operations might be noble (for instance land redistribution to landless people), the whole focus is shifted when politics, dramatisation and disorderliness present themselves onto the fore. If land redistribution is undertaken in an orderly manner, deserving citizens would be allocated with fare shares of pieces of land as opposed to the elite in government hijacking it. Ankomah (2002) has summarised it by saying:

Evidence of ZANU (PF) insincerity in the land project manifested itself in widespread elite manipulation of land redistribution, the fact that ZANU (PF) supporters were the main beneficiaries, and the reality that there was little facilitation or support for postinvasion agricultural and settlement initiatives.

Ankomah's finding is reliable given the information that has been hitting the headlines that government officials own more than one farm whereas the majority of Zimbabweans did not acquire productive pieces of land in the controversial land redistribution programme. The majority of Zimbabwean poor lives in rural areas and land resettlement should have accounted for this category of beneficiaries first. It is therefore suggested that beneficiaries of land resettlement should be supported by research, funds and other resources, including machinery.

\section{Commercialising Farming}

By commercialising, I mean turning farms and government land into vibrant business entities that will generate income for the individual tenants and/or for the nation as a whole. This involves advertising government farms to be leased towards purchase. Farmers on lease agreements are to be supplied with inputs which they pay for at the end of the farming season. Loans in order to pay salaries for labour and cover costs for equipment during the farming season should be made available to these farmers. Proper contractual agreements should be entered into between the farmer and government/loaning institution so that failure to repay the loan is liable to prosecution. The following parastatals facilitate funds, material and human resources, as well as technical resources to guarantee the success of this ambitious project: Agricultural Bank (AGRIBANK), Agricultural Research and Extension (AREX), Agricultural Rural Development Authority (ARDA), Grain Marketing Board (GMB), Pig Industry Board (PIB), The Cold Storage Commission (CSC), Tobacco Industry and Marketing Board (TIMB) and Tobacco Research Board (TRB).

The Zimbabwean political leadership, community leaders and religious leaders should demilitarise the land reform. As it is now, most leaders have more than one farm. The majority of the rural people who deserved land did not get it while the 'elite' wrestled among themselves to acquire land. Cabinet Ministers and City Council's officials have showered themselves with farms that they are not using. If the Zimbabwean government is serious about alleviating poverty among its citizens, land allocation priorities should be given to the landless people, most of whom continue to cultivate on overused and unproductive soil. In addition, land allocation to graduates from agricultural colleges is essential in improving agricultural productivity in Zimbabwe. Zimbabwean institutions of higher learning have in recent years produced graduates in the field of agriculture. Instead of incorporating or absorbing most of these graduates in academia and in other government departments as officers or researchers, there should be a promotion drive on the part of the Ministry of Agriculture to offer land for farming, so that they make maximal use of their skills to enhance the agricultural sector. This will also make the new farmers become entrepreneurs or masters of their own enterprises in the long run. Given Zimbabwe's drive 
towards property and business ownership, this move becomes a positive and necessary step towards achieving that goal. Added to that, Government should support new farmers with financial and material resources and equipment to cultivate land. Bank loans for salaries and farm inputs (i.e., fertilizers, seeds, pesticides, etc.) should be facilitated for new farmers. The loans could be payable at the end of the farming season.

\section{Dam Construction}

Zimbabwe has always been prone to drought leading to famine and starvation. Construction of dams across the country will serve as one of the remedies for this eventuality, alongside producing and storing an abundance of food during years of plenty. The Ministry of Water Resources and Infrastructural Development should be tasked to begin constructing dams, while other government ministries and departments should see that research, technical and material support are supplied.

\section{Sinking Boreholes}

Water has become a crisis in most parts of Zimbabwe, both rural and urban. The Zimbabwe National Water Authority (ZINWA) has been faced with a water challenge for over a decade. Most communities in Zimbabwe rely on borehole water as the government and city authorities have failed to provide adequate, tapped, clean water to residents (Raath, 2008:6). The construction and maintenance of water points, especially boreholes, is important in making water accessible to poor communities who struggle daily to make a decent living. The continued water crisis makes the communities vulnerable to waterborne diseases such as cholera, typhoid and bilharzias, among others. NGOs such as Red Cross have embarked on a programme of sinking boreholes to salvage the water crisis in Zimbabwe's major cities. The Zimbabwean government should complement efforts by NGOs by providing a stable political climate for providing such social amenities. As the source of life for all, water is needed even if people have only a piece of land in the backyard where they can plant vegetables and legumes to sustain their livelihoods. In the absence of rain water, households can utilise irrigated water for their plants in the garden. One does not only need bigger space of land to begin working on a nature-given resource; agricultural productivity can occur anywhere as long as water is made available. If everyone in government is committed to playing their part, the agricultural sector will grow, making SED in Zimbabwe a possibility. The same proposal was put forward by Pazvakavambwa (2011:176) who advanced the view that the effectiveness of the Ministry of Agriculture and its departments must be restored and strengthened in order to achieve food security at both national and household levels.

\section{Examining Poverty in Zimbabwe}

\section{Definition of Poverty}

Poverty can be defined as a pronounced deprivation of well-being related to lack of material income or consumption, low levels of education and vulnerability, and exposure to risk, no opportunity to be heard and powerlessness (World Bank, 2001:1). Ukpong (1995:31) defines poverty as a condition whereby the victims are alienated from access to resources that would enable them live a fully human life in society. Poverty reduction can be defined as successfully lessening deprivation of well-being (Sunderlin et al., 2003:61-73; 2004:1). It follows that those who are poor are usually excluded from the mainstream political and socio-economic activities. Binza (2007:4) affirms that poverty and exclusion are multi- 
dimensional phenomena. The causes (to be discussed below) of poverty and exclusion are to be found in social, political, and economic factors. Parnell et al. (2002:56) define the poor as those who are chronically hungry, perennially needy and pathetic, and have no or limited access to economic, educational, political and social resources. Following up on these sentiments, are Patel et al. (2002:31) who concur that lack of economic, social, human, physical, and environmental assets by the poor is considered to have a link to vulnerability and exposure to poverty and exclusion. Patel et al. (2002:33) further lament that poverty and exclusion are associated with the pain that comes with too little or no food for some days; lack of shelter and jobs, or long hours of work with little pay; emotional pain stemming from daily humiliations of dependency, and lack of power, limited access to information held by government and private financial authorities. Patel et al.'s articulation is followed up by Daphne's (1998:28) opinion that on average the rural households spend more than three to five hours daily fetching water, and another five to six hours are spent on collecting dung and wood to make fire. This category of the population is hit hard because the poorest of the poor reside in the rural peripheries of the country. They are faced with a number of barriers that prohibit them from increasing their economic productivity (Binza, 2007:5). Having defined what poverty entails and explained the context of the poor of society, this study discusses some of the causes of poverty particularly among Africans.

\section{Introspection of Causes of Poverty}

Causes of poverty in Africa in general, and in Zimbabwe in particular, are numerous. The deepening of poverty among communities in Africa is exacerbated by lack of economic growth.

These causes which are incompatible with a national plan of action towards SED present themselves as impediments which prohibit government to achieve its objectives for economic growth to prevail in the country, consequently exposing the majority of people to extreme poverty. The following factors will be explored: (1) geography of a country, (2) vandalism and plundering of natural resources, (3) land grabbing and invasions, (4) less tropical rains and drought, and (5) exclusion and inclusion.

\section{Geographical Location}

The geographical location of a country determines how efficiently that country can respond to bilateral and international business transactions. The following data will attempt to give a brief sketch (pictorial view) of Zimbabwe to show how the country's geographical location can affect its productivity:
- Area :
Total of $390580 \mathrm{~km}^{2}$ (water: $3910 \mathrm{~km}^{2}$ and land $386670 \mathrm{~km}^{2}$ )
- Climate :
Tropical: rains from November to March
- Location :
Southern Africa
- Land boundaries :
- Coastline :
Borders: Botswana, South Africa, Mozambique and Zambia
- Terrain :
None: Zimbabwe is landlocked
High plateau: high veldt (mountainous in the east)

In the context of the above data, I concur with Sachs and Warner (1996:339) who have clearly stated that a country's geography affects growth. Countries which are geographically isolated from world markets will face higher costs for all international activities, and may end up with lower division of labour and lower output per capita. Landlocked countries (e.g., Zimbabwe) face very high costs of shipping, since they must pay road transport costs across at least one international boundary, in addition to sea freight 
costs. Given the location of Zimbabwe as stated by Sachs and Warner, the total costs of shipping and road transport will have a negative effect on the economic lives of the majority of Zimbabweans, most of whom reside in the rural areas where the same product will also add another transport cost to reach rural consumers. Even in times of political unrest or an economic embargo, a country like Zimbabwe and its people will have to struggle for survival. The economic sanctions slapped on the Zimbabwean leadership by the international community had a negative impact on the economy of the country as a whole, exacerbated by its geographical. Zimbabwe is a landlocked country, surrounded by South Africa in the south, Mozambique in the east, and Namibia in the west, which are endowed with sea waters.

\section{Vandalism and Plundering of Natural Resources}

Sachs and Warner (1996:341) note that natural resource abundance is included as a determinant of growth. Natural resource exports are defined as the sum of exports of primary agriculture, fuel and minerals. Zimbabwe being an agro-economy, commercial agriculture has been affected by the fast-track land reform programme and agricultural productivity had deteriorated drastically, which has also affected exports of agricultural products (e.g., tobacco, citrus, cotton, maize, wheat, soya beans, etc.). Zimbabwe is not a fuel producing country. All fuel is imported from outside, whose shipping costs also affect the pricing of goods and services. This has a negative impact on the consumer, especially the poor. Minerals are abundant in Zimbabwe; recently, diamond has emerged as moneyspinning for individuals in Zimbabwe, while vandalism and plundering of this precious stone has claimed many lives (cf. Powell \& Thorneycroft, 2010:8; Moore, 2012:6). Ian Smillie, among other sources, have revealed that both the police, the army and ZANU (PF) political figures clashed with the local people in Marange (Mutare) in a desperate bid to secure this natural wealth. ${ }^{5}$ It has also been revealed that a Russian mining company has found diamond deposits on the farm confiscated from exiled MDC treasurer Roy Bennett (Nqindi, 2012:6). It is further reported that ever since Bennett left the farm in 2004, diamonds were being looted by those in positions of power (Nqindi, 2012:6). This might be a tip of the iceberg, and a lot more vandalism and looting of natural resources might have occurred on a big scale at the expense of sustainable development of the entire nation and its people. The negative impact of corruption to economic growth is articulated by Mauro (1995:683) who has reiterated that corruption lowers private investment, thereby reducing economic growth, even in subsamples of countries in which bureaucratic regulations are very cumbersome. Mauro goes on to say that the negative association between corruption and investment, as well as growth, is significant, both statistically and economically.

\section{Land Grabbing and Invasions}

Zimbabwe's economic collapse came about as a result of the government policy, particularly on the controversial land redistribution programme from land reform to land occupation $^{6}$ which was begun in the late 1990s. Blair (2008:15) clearly articulates the negative impact of the invasions, lamenting that by seizing white-owned farms and handing them out to his cronies without providing them with farming equipment, training

See Smillie, Ian (2009). Zimbabwe, Diamonds and the Wrong Side of History. Partnership Africa Canada. Occasional Paper No. 8.

6 See De Villiers, B. (2003). Land Reform: Issues and Challenges. A Comparative Overview of Experiences in Zimbabwe, Namibia, South Africa and Australia, 5-28. Johannesburg: Konrad-Adenauer-Stiftung. 
or even title deeds, Mugabe wrecked commercial agriculture. Since the year 2000 when the invasions increased, the collapse of the agricultural sector has crippled Zimbabwe's economic life.

\section{Less Tropical Rains and Drought}

Sachs and Warner (1996:339) maintain that Sub-Saharan Africa has a high proportion of the population in tropical climates. Casual observation suggests that countries located in the tropics tend to grow more slowly than those in the more temperate climates. Sachs and Warner further affirm that in African countries within the tropical regions, soil tends to be more fragile, rains less reliable, pests and veterinary diseases more prevalent, and natural disasters more frequent, all of which impede sustained agricultural growth in the tropics (1996:340).

Zimbabwe is one of the countries in the Sub-Saharan Africa within the tropical region. Zimbabwe's rainfall pattern is unpredictable, as drought has sometimes devastated the country's agricultural productivity. A large part of Zimbabwe's population is demographically situated in the rural areas, some of them in rocky soils which are unable to cope up with the tropical heat when the rainfall is mild, resulting in drought. Many rural households are prone to poverty and starvation due to low rainfall. The agricultural sector as a whole suffers because of shortage of rain, resulting in fewer yields. Given that Zimbabwe is an agro-economy, this lack of tropical rain will have a devastating effect on the economy of the country as a whole. All these factors together impact heavily on the poor. The Executive Summary (2009:3) has confirmed that the majority of Zimbabweans still reside in communal and original settlement areas and this is where most of the poor are found.

\section{Exclusion and Inclusion Ideologies}

The exclusion and inclusion ideologies (Dorman, 2003:845-863) previously practiced by ZANU (PF) will impede SED in the near future. The systematic characterisation of fellow citizens or their personality as White, Black, Shona, Ndebele, war veterans, identity, or citizenship, tends to discriminate against other people and so include some and deliberately exclude others from being part of the programme in running the affairs of government on the one hand, and the nation as a whole on the other. In previous years, the ZANU (PF) government had employed the ideology of exclusion and inclusion in order to divide and rule as a strategy towards a government composed largely of either war veterans or Shonadominated ruling elite, while the minorities and non-war veterans are excluded. In the South African context, I am reliably informed that the same is true of ANC in which President Jacob Zuma's entourage is composed largely of the Zulu and the Xhosa and very few or none from the Sotho/Tshwana/Pedi or Venda ethnic tribes, worse still those who do not have anti-apartheid and or liberation credentials. ${ }^{7}$ The above scenario portrays that in both South Africa and Zimbabwe democracy and voting processes remain strongly aligned according to race. ${ }^{8}$ Kriger $(2003: 208)$ correctly advances the same opinion that guerrilla veterans and the ruling party worked closely together and manipulated each other when necessary, to gain and retain power and privilege in national institutions such as the army,

A similar opinion was expressed by Nomboniso Gasa's 'ANC crisis of leadership reflects a broader malaise', Sunday Independent 22 October 2006.

8 Harris, M 2014. South Africa: 2014 elections forecast and political scenarios for the next decade. Political Strategy February 6. Online at: www.etmanalytics.com. Accessed 19 February 2017. 
the police and the civil service and also within the labour organisations. In my view, when Ottuh (2013:258) talks of 'domestic captivity,' he also refers to these exclusion and inclusion ideologies in the Zimbabwean context. In various cases, the minorities are entitled to some kind of rights, but excluded from others (Ariely, 2011:241). Mlambo (2006:407) also articulates that these tactics were used time and again in the first decade of independence to advance the interests of the war veterans and the ruling party. Some sources say that the clean-up exercise of 2005 code-named Operation Murambatsvina (Rugwiji, 2011:126) was an exclusion and inclusion tactic intended to push to rural areas city dwellers, most of whom were alleged to be migrant workers, who had come to Rhodesia (now Zimbabwe) from countries such as Malawi, Zambia and Mozambique, who were perceived as 'non-indigenous.' According to ZANU (PF) terms, these categories of citizens (or non-citizens) had contributed to the formation of and voted for MDC. In addition, most of the farm workers were entangled in the political unrest involving white commercial farmers who were accused of forming and funding MDC (Rutherford, 2011:501).

The government is largely composed of people who were former freedom fighters, particularly those who belonged to the ruling party ZANU (PF). The majority of cabinet ministers were drawn predominantly from those who were believed to have participated actively in the liberation struggle under the ZANU (PF) ticket in one way or another. Others, such as whites (who are unfortunately linked to the previous colonial rule) are perceived to be members of the opposition, thus regarded as persona non grata. The reason why Morgan Tsvangirai, among others, is excluded from the mainstream political constituency according to ZANU (PF)'s terms is because he cannot be traced to the liberation struggle for Zimbabwe's freedom. Other people are excluded on the grounds of ethnicity. For example, Joshua Nkomo's Ndebele people are culturally alienated in the affairs of government. Although he was a well-known revolutionary alongside Mugabe, Nkomo was sidelined because he was leader of a dominated rival party, namely PF-ZAPU.

Zimbabwe's independence is believed to be the result of the divine intervention of the spirit mediums such as Nehanda, Kaguvi and Chaminuka (see Kazembe 2011:89-98). These spirit mediums are believed to have guided the freedom fighters in their struggle for liberation against Ian Smith's colonial government. The Christian God is believed to function in the larger framework of local and cultural belief systems which involve spirit mediums who act precisely towards the emancipation of Africans. Most of the people linked to ZANU (PF)'s revolutionary ideology do not hold Christianity in high esteem although they believe in God (Musikavanhu/Nyadenga). In my view, this ideology arose from the sensitisation during the liberation struggle that Christianity was the colonial religion which the 'white man' used to subjugate the Africans in Rhodesia (now Zimbabwe). Those opposed to these ideological values cannot constitute the ZANU (PF) government. Government officials adherent to other belief systems rarely hold influential positions. To a large extent, the present Zimbabwean government is characterised by these virtues. Having discussed the causes of poverty in Zimbabwe, the following section now focuses on elucidating strategies towards poverty.

\section{Strategies towards Poverty Reduction in Zimbabwe}

\section{Agriculture}

According to the Executive Summary (2009:3) an agriculture-led strategy provides the most direct way to address poverty, enhance employment and kick-start growth. This strategy entails reviewing the previous land reform. The government should repossess farms on 
which no meaningful farming activities are taking place and allocate them to graduates from agricultural colleges who have the skills and the expertise to work on the land. Commercial farmers, who lost their farms in the previous land invasions in Zimbabwe, will be allocated farms of their choice for them to resume farming . Farmers will advertise for resumption of farming activities in the media for jobs, in order to attract previous farm workers who were displaced elsewhere, but would be willing to rejoin the agricultural sector for economic survival. Productivity which derives from the agricultural sector has the potential of boosting the economy in Zimbabwe within a few years of the resumption of commercial farming activities. Crops such as maize, tobacco, soya beans, wheat, citrus, beans, cotton, sunflower, and many others, have traditionally provided exports from which Zimbabwe got foreign currency. The reserves of foodstuffs at the Grain Marketing Board (GMB) and other storage facilities provided enough food for Zimbabweans. Many companies which closed down during the economic meltdown of the previous years could not survive without raw materials drawn largely from agriculture.

\section{ICT}

Zimbabwe is ranked among the lowest countries in the world for information technology, placed on 132nd position out of a total of 134 countries in 2009 (Executive Summary, 2009:10). President Robert Mugabe had embarked on a national programme of donating computers to Zimbabwean schools. However, putting aside the so-called campaign gimmick on the part of President Mugabe, introduction of computers in schools was noble. The computer programme must be followed up as this will improve the knowledge of learners rather than waiting until they get to university or college to learn information and communication technology. The modern world is being dictated by computer skills, and information technology streamlines learners to access new and well-researched ideas through computers. My opinion concurs with Bukaliya and Mubika (2011:415)'s observation that in a global village, technology has become the thing, as countries and organisations devise means of gaining competitive edge over others. ICT plays a key role in linking businesses and individuals far apart in terms of geographical distance. Bukaliya and Mubika have also commented that, in pursuit of the objectives to ensure that the country advances its technology base, Zimbabwe, through the Ministry of Education, has introduced the computer education in the school curriculum (2011:415). In addition to Bukaliya and Mubika's analysis, graduates who have learned information technology have a better chance of either getting employment or starting their own businesses involving computers. Internet cafes are examples of such businesses, which thrive because everyone wants to access the 'outside' world through the internet.

\section{The Return of Human Capital}

During a decade of economic meltdown, Zimbabwe experienced major human capital loss.

Some migrants working as professionals overseas have gained valuable experience. Government will need to find ways to lure them back to share their skills and knowledge (Executive Summary, 2009:11). Some of the migrants who are still living in Diaspora have accumulated both wealth and skills, which will contribute immensely towards developing Zimbabwe. Poverty reduction in Zimbabwe is a collective effort. Zimbabwean migrants need to consider returning home to develop the country along with the rest of the people. However, it has been learned that some of the migrants will not return as long as Robert Mugabe remains the influential principal in the present government. My anonymous 
sources have expressed the notion that even though many migrants are prepared to return home, they have adopted a 'wait-and-see' approach, in anticipation of Mugabe's resignation as President of Zimbabwe. The majority of the Diaspora community is opposed to Mugabe's rule. In my view, Zimbabweans abroad do not nurture these wishful thoughts for personal or individual gain; but rather for national pride.

\section{The Neighbourhood Effects}

Economic performance and political unrest of neighbouring countries in Sub-Saharan Africa have some effects on the economy of the others within the region. I concur with Sachs and Warner (1996:350) who have stated that a country's growth depends also on the growth of the economies of neighbouring countries. Individual countries are held back not just by their own policies, but also by the policies of their neighbours. The above assertion by Sachs and Warner could be authentic when one takes into account political and socioeconomic relations between South Africa and Zimbabwe. Zimbabwe's economic survival in the last decade was primarily due to the support rendered by South Africa. Within South Africa itself, the high shortage of jobs in the country can be attributed to thousands of migrants (the majority of them Zimbabweans), who are economically employed in South Africa, thereby competing with the natives for limited job opportunities. One would therefore want to see the Zimbabwean economic growth be given high priority so that South Africa's own burden of "carrying Africa's crises" will be resolved to some extent. The exodus and xenophobic attacks on Zimbabweans (and other African migrants) by South Africans are consequences of economic failure back home.

\section{The International Community}

Zimbabwe has numerous economic challenges due to its location as a land-locked country. During the time when economic activities were halted by political power games in Zimbabwe, calls were made from a cross-section of society both within and outside Zimbabwe, for South Africa and Mozambique to close the borders with Zimbabwe. If this measure had succeeded and been implemented by the countries concerned, it was going to aggravate the suffering of the poor. The international community not only needs to be called upon to play the role of arbitrator to resolve political conflicts, but also to salvage economic crises or coastal differences. Sachs and Warner (1996:351) have reiterated that it is a very high priority for landlocked countries (e.g., Zimbabwe) to gain efficient low cost transport to coastal port facilities. The international community can be called upon to help ensure this, partly through infrastructure financing and partly through mediation of political conflicts that impede the market access of landlocked countries. In such cases, the Zimbabwean government may appeal to the international community in order to effect or implement this mechanism.

\section{Conclusions}

This essay has explored the question of land during ancient biblical times. Although issues pertaining to land have been articulated in other periods of the Jewish history, the focus of the discussion was the Persian period. The study showed that Yahweh had made a covenant with the patriarchs to give them land. The exodus narrative which threads through the entire biblical text concerns the land given by Yahweh to his chosen people, the Israelites. It was shown that land was critical in ancient Israel as it is in our contemporary context. The article demonstrated that farming constituted the mainstay of economic sustenance in ancient Israel in which crops of various types were grown. Agriculture (including 
subsistence farming) supplied both domestic consumption and national demand. Payment of tax to the government was made from the produce of the land. It was argued that failure to revere Yahweh, including corruption, oppression of the poor and questions of unethical conduct and immorality made the Jews lose their land through deportation and captivity in Babylonia. The Judeans were restored to their land from exile through Cyrus. It was discussed that the postexilic literature such as Trito-Isaiah, Ezra-Nehemiah, Zechariah, Haggai, and Malachi, among others, showed that there was a time of economic euphoria in Yehud. However, the rebuilding of the temple, Yahweh's place of worship and reverence, was neglected as the Judeans focused attention on survival matters such as building their homes while the temple lay in ruins. It was revealed that the temple served as the centre for the reverence of Yahweh as his dwelling place. It also functioned as a storehouse for food and for collection of tax for the Persian government.

In this essay, themes within the postexilic narratives surrounding the land question in Yehud were appropriated in the Zimbabwean context in which the land debate has been the cause of controversy and economic meltdown for over ten years. Agriculture plays a key function in the SED of Zimbabwe. Most Zimbabweans depend on the produce from farming such as maize, tobacco, soya beans, pumpkins, sugar beans, tomatoes, potatoes, sweet potatoes and many other crops. That is why land resettlement is of critical importance in Zimbabwe. However, land resettlement must be conducted in an orderly manner. Zimbabwe's fast-track land reform programme had caused serious economic meltdown in the country. Until now at the time of finalising this discussion, consequences which emanated from the crisis over land include collapse of commercial farming, closure of industry, unemployment, escalation of poverty, and the exodus of professionals to foreign land such as South Africa, Mozambique, USA, UK, Australia, and other places.

This article has discussed the need for a theology of reconstruction by employing strategies towards SED and poverty reduction in the country. First and foremost, it was proposed that the Zimbabwean leadership needs to review and revise its land policy. There is need to conduct a survey on agricultural activities among new farmers to establish whether these farms are being utilised maximally. I still believe that where no serious farming is being done, such farms must be repossessed by government and be given to qualified individuals who will be able to be productive on the farm in order to sustain both domestic consumption, national demand as well as supply for export. Second, the return of human capital (in view of the skilled people in Diaspora) was articulated. A conducive political climate will lure Zimbabwean citizens in Diaspora to return home to rebuild their country. Third, the question of effects of Zimbabwe's neighbours has been highlighted. The economic growth of Zimbabwe is also dependent on the economic growth of other countries in the region. Last, Zimbabwe needs to consider improving international relations, especially in terms of revising the country's foreign policy in order to attract investment into the country. Economic empowerment of locals (in view of Empowerment and Indigenous Act) is necessary. However, it must be implemented in such a way that it does not present itself as an impediment to potential business people outside our borders who would want to invest in Zimbabwe.

I would not subscribe to the suggestion opined by scholars such as Ahmed Audu Maiyaki who says "the government (of Zimbabwe)" should consider the possible consequences of the conditionality of IMF/World Bank before accepting any package from them" (2010:4159). I have argued in other writings that the Zimbabwean narrative of

9 The insertion is mine. 
political and socio-economic crises since the early 2000s has recently been interpreted (and incorrectly so) from the outsider's perspective. By 'outsider' I am not being racial here; if Maiyaki had been in Zimbabwe particularly the beginning of 2008, I am convinced that he would agree to revise his/her opinion. In 2008, a wheelbarrow of bearer cheques (not real money) was buying nothing but a loaf of bread (of about 700g). Voluminous contributions have already been published to date about Zimbabwe's hyperinflationary environment up to 2008. So, the suggestion of refuting IMF/World Bank's conditionality as the author pointed out does not make economic sense for the majority of Zimbabweans who are already ravaged by socio-economic crises ever to be experienced in Africa (if not the whole world, not even in Germany). The IMF or World Bank does not impose a country to adhere to unjust conditions; the financiers would like to ensure availability of trusted responsibility so that financial assistance is not channelled for undesignated programmes. If the Zimbabwean government attempts to play 'the big brother's role' it is the already poverty-stricken Zimbabweans who will continue to suffer. I would suggest that the Zimbabwean leadership revise its foreign policy, respect and implement the rule of law in the country which for now is non-existent. That, in my view, has been the bone of contention expressed all over by peace-loving and democracy-seeking individuals and organisations, including potential investors. In my opinion, as Zimbabweans, we should 'swallow our pride' for the common good of the nation. That is the required bigger picture.

\section{BIBLIOGRAPHY}

Albright, WF 1940. The Ancient near East and the Religion of Israel. Journal of Biblical Literature 59 (2), 85-112.

Allegro, MJ 1971. The Chosen People: A Study of Jewish History from the Time of the Exile until the Revolt of Bar Kocheba. London: Hodder and Stoughton.

Ankomah, B 2002. Righting the Colonial Wrong. The Sunday Mail. 10 March.

Ariely, G 2011. Exploring Citizenship Spheres of Inclusion/Exclusion: Rights as potential Power. Patterns of Prejudice 45, 3:241-258.

Ashton, M 1992. The Exiles return. Worcester: Billing and Sons.

Bean, AF 1991. Persia. Holman Bible Dictionary. Nashville, Tennessee: Holman Bible Publishers.

Berlin, A 2005. Psalms and the Literature of Exile: Psalms 137, 44, 69 and 78, in Flint, PW \& Miller, PD (jnr.) (eds.), The Book of Psalms: Composition and Reception, 65-86. Boston: Brill.

Binza, SM 2007. South African Government Policies: Towards Combating Poverty and Exclusion. Joernaal Eietydse Geskiedenis 1 December, 4-5.

Blair, D 2008. How to rebuild Zimbabwe after Mugabe. The Star 3 April, 15.

Blenkinsopp, J 1988. Ezra-Nehemiah: A Commentary. Philadelphia: Westminster.

Brueggemann, W 1985. Hopeful Imagination. Philadelphia: Fortress.

Bryne, T 1988. Working for Justice and Peace: A Practical Guide. Ndola: Ndola Mission Press.

Bukaliya, R \& Mubika, AK 2011. Teacher Competence in ICT: Implications for Computer Education in Zimbabwean Schools. International Journal of Social Sciences and Education 1, 4:414-425. 
Cartwright, C 2004. Reviews. Palestine Exploration Quarterly 136, 1:88-89.

Cataldo, JW 2009. A Theocratic Yehud? Issues of Government in a Persian Period. New York: T\&T Clark.

Clements, RE 1965. God and the Temple. Oxford: Basil Blackwell.

Clements, RE 1965. Deuteronomy and the Jerusalem Cult-tradition. VT 15, 300-312.

Clements, RE 1968. God's Chosen People: A Theological Interpretation of the Book of Deuteronomy. London: SCM.

Coltart, D 2008. A Decade of Suffering in Zimbabwe: Economic Collapse and Political Repression under Robert Mugabe. Centre for Global Liberty \& Prosperity. Policy Analysis No. 5, 1-24, 24 March.

Compagnon, D 2011. A Predictable Tragedy: Robert Mugabe and the Collapse of Zimbabwe. Philadelphia: University of Pennsylvania Press.

Dandamaev, MA \& Lukonin, VG 1989. The culture and social institutions of ancient Iran, tr. by Kohl, PL Cambridge: Cambridge University Press.

Daphne, J 1998. Getting South Africa Working. Naledi Policy Bulletin 1 (2), April.

De Vaux, R 1965. Ancient Israel: Its Life and Institutions. Darton: Longman and Todd.

De Villiers, B 2003. Land Reform: Issues and Challenges. A Comparative Overview of

Experiences in Zimbabwe, Namibia, South Africa and Australia, 5-28.

Johannesburg: Konrad-Adenauer-Stiftung.

Dorman, RS 2003. NGOs and the Constitutional Debate in Zimbabwe: From Inclusion to Exclusion. Journal of Southern African Studies 29, 4:845-863.

Ellickson CR \& Thorland, DC 1995. Ancient Law: Mesopotamia, Egypt, Israel. Paper 410:328-408.

Eph‘al, J 1988. Syria-Palestine under Achaemenid Rule. Cambridge Ancient History IV. Cambridge: Cambridge University Press.

Fager, JA 1987. Land Tenure in the Biblical Jubilee: A Moral World View. Hebrew Annual Review 11, 59-68.

Farisani, BE 2010. Black Biblical Hermeneutics and Ideologically Aware Reading of Texts. Scriptura 105:507-518.

Forbes, RJ 1993. Science and the Crafts in the Ancient Near East. Tractrix 5:139-159.

Frye, R 1970. Persia. The World Book Encyclopedia. Toronto: Field Enterprises Educational Corporation.

Gasa, N 2006. ANC Crisis of Leadership Reflects a Broader Malaise. Sunday Independent 22 October.

Gathogo, J 2009. African Theology of Reconstruction as a Practical Theology for all. Practical Theology for South Africa 24:99-121.

Goldingay, J \& Wright, CJH 1991. How does the First Testament look at other Religions? in Clarke, AD \& Winter, BW (eds.), One God, one Lord in a World of Religious Pluralism, 34-52. Cambridge: Tyndale House.

Grabbe, LL 2000. Judaic Religion in the Second Temple Period: Belief and Practice from the Exile to Yavneh, London: Routledge.

Gray, J 1964. The Canaanites. London: Thames and Hudson. 
Harris, M 2014. South Africa: 2014 Elections Forecast and Political Scenarios for the Next Decade. Political Strategy February 6. Online at: www.etmanalytics.com. Accessed 19 February 2017.

Hasel, G F 1983. Healing in the Old Testament. Andrews University Seminary Studies 21, 3:191-202.

Hanson, PD 1987. Israelite Religion in the Early Postexilic Period, in Miller, P, Hanson, PD \& McBride, D (eds.), Ancient Israelite Religion, 485-508. Philadelphia: Fortress.

Heyns, D 1992. Time and Reality: Science in Dialogue with the Prophet Amos, in Wessels, W \& Scheffler, EH (Eeds.), Old Testament Science and Reality, 257-276. Pretoria: Verba Vitae.

Holmgren, FC 1987. Ezra and Nehemiah: Israel Alive Again. Grand Rapids: Eerdmans. Howard-Hassmann, RE 2010. Mugabe's Zimbabwe, 2000-2009: Massive Human Rights Violations and the Failure to Protect. Human Rights Quarterly 32, 4:898-920.

Human Rights Watch, (2002). On Farm Workers. Harare: HRW.

Johnson, AR 1970. Psalm 23 and the Household of Faith, in Durham, JJ \& Porter, JR (eds.), Proclamation and Presence: Old Testament Essays in Honour of Gwynne Henton Davies, 255-271. Richmond: John Knox Press.

Kanael, B 1963. Ancient Jewish Coins and their Historical Importance. The Biblical Archaeologist 26, 2:37-62.

Kärkkäinen, VM 2003. An Introduction to the Theology of Religions. Downers Grove, IL: InterVarsity Press.

Kazembe, T 2011. Divine Angels and Vadzimu in Shona Religion, Zimbabwe. Rose + Croix Journal 8:89-98.

Kriger, N 2003. Guerrilla Veterans in the Post-war Zimbabwe: Symbolic and Violent Politics, 1980-1987. Cambridge: Cambridge University Press.

Kuhrt, A 1983. The Cyrus Cylinder and Achaemenid Imperial Policy. JSOT 2: 83-97. Kunhiyop, SW 2008. African Christian Ethics. Nairobi: WordAlive.

Leeming, D 2004. Jealous Gods and Chosen People: The Mythology of the Middle East. Oxford: Oxford University Press.

Leick, G 2003. Historical Dictionary of Mesopotamia. Maryland: The Scarecrow Press.

Le Roux, M 1992. Shared Power in the Promised Land, in Wessels, W \& Scheffler, E (eds.), Old Testament Science and Reality, 14-154. Pretoria: Verba Vitae.

Maiyaki, AA 2010. Zimbabwe's Agricultural Industry. African Journal of Business Management 4, 19:4 159-4 166.

Majaka, N 2017. Zim Cash Crisis Worsens. Daily News 5 April.

Maluleke, T 1994. The Proposal for Theology of Reconstruction: A Critical Appraisal. Missionalia 22, 3:245-258.

Maluleke, T 1996a. Black and African Theologies in the New World Order: A Time to Drink from our own Wells. Journal of Theology for Southern Africa 96:3-19.

Maluleke, T 1996b. Review of Mugambi, JNK from Liberation to Reconstruction: African Christian Theology after the Cold War. Nairobi: East African Educational Publishers. Missionalia 2: 473. 
Maluleke, T 1997. Half a Century of African Christian Theologies: Elements of the Emerging Agenda for the Twenty-First Century. Journal of Theology for Southern Africa 99:4-23.

Mamdani, M 1991. Social Movements and Constitutionalism in the African Context, in Shivji 1991:s n.

Mangena, F 2009. Platonic Justice and Zimbabwe's Eight Dark Years of Political Polarization: Is merit-based Democracy Tenable? Phronimon 10, 1:71-87.

Maré, LP 2010. Psalm 137: Exile - not the Time for Singing the Lord's Song. Old Testament Essays, 23, 1:116-128.

Maundeni, Z 2004. Why the African Renaissance is likely to fail: The Case for Zimbabwe. Journal of Contemporary African Studies, 22, 2:189-212.

Mauro, P 1995. Corruption and Growth. The Quarterly Journal of Economies 110, 3:681-712.

Mhlanga, P 2016. Banks to Double Point of Sale Machines. The Financial Gazette 14 July. Miller, LM 2010. Nehemiah 5: A Response to the Philippe Guillaume. The Journal of Hebrew Scriptures 10, 13:1-7.

Mlambo, A 2006. Guerrilla Veterans and the Third Chimurenga. Journal of Southern African Studies 32, 2:406-408.

Moltmann, J 1985. Inviting the Triune of God, in Geffre, C, Jossua, JP \& Lefebure, M. (eds.), Monotheism, 50-58. Edinburgh: T\&T Clark.

Moltmann-Wendel, E 1986. A land flowing with Milk and Honey. London: SCM.

Nsingo, SAM \& Kuye, JO 2005. Democratic Participation for Service Delivery in Local Government in Zimbabwe: Humanising Structural Configurations and Legal Provisions. Journal of Public Administration 40, 4:744-760.

Moore, C. (2005). Mugabe to speak at hunger debate as he defies EU travel ban again. The Telegraph (London). Online: http://www.telegraph.co.uk/news/main.jhtml? Accessed 3 January, 2011.

Moore, D 2012. Progress, Power and Violent Accumulation in Zimbabwe. Journal of Contemporary African Studies 30:1-9.

Motyer, JA 1999. Isaiah: An Introduction and Commentary. Illinois: IVP Academic.

Mugambi, JNK 1991. The Future of the Church and the Church of the Future in Africa, in Chipenda, JB, Karamaga, A, Mugambi, JNK \& Omari, C, (eds.), The Church of Africa: Towards a Theology of Reconstruction. Nairobi: AACC.

Mugambi, JNK 1995. From Liberation to Reconstruction. Nairobi: East African Educational Publishers.

Mugambi, JNK 2010. Theology of Reconstruction, in Stinton, DB (ed.), African Theology: Current Conversations, 139-149. London: SPCK

Mwaura, PN 2010. Christian Identity and Ethnicity in Africa: Reflections on the Gospel of Reconciliation, in Stinton, DB (ed.), African Theology: Current Conversations, 128-138. London: SPCK.

Myers, J 1965. Ezra, Nehemiah: Introduction, Translation, and Notes, AB 14. New York: Doubleday. 
Ndlovu-Gatsheni, JS 2009. Making Sense of Mugabeism in Local and Global Politics: 'So Blair, keep your England and let me keep my Zimbabwe.' Third World Quarterly 30, 6:1139-1158.

Nkurunziza, JD 2008. A Paper presented at the Ninth Annual Global Development Conference on Security for Development: Confronting Threats to Safety and Survival, 26 January 26 to February 2, 2008 at the United Nations Conference on Trade and Development (UNCTAD), Geneva, Switzerland. Online: http://www.afdb.org/fileadmin/uploads/afdb/Documents/Knowledge/30754226-FR-NKURUNZIZA-TUNIS.PDF. Accessed 1 November, 2012.

Noth, M 1960. The History of Israel, Rev Ed. New York: Harper \& Row.

Nqindi, J 2012. Diamonds found on Zimbabwe Farm. Sunday Times 24 June, 6.

Nsingo, SAM \& Kuye, JO 2005. Democratic Participation for Service Delivery in Local Government in Zimbabwe: Humanising Structural Configurations and Legal Provisions. Journal of Public Administration 40, 4:744-760.

Nürnberger, K 2003. God's Mission Practice: The struggle for Liberation, Dignity and Justice in African Societies. International Review of Mission 92, 367:498-520.

Orlin, LL 2007. Life and Thought in the Ancient Near East. Ann Arbor: The University of Michigan Press.

Ottuh, JA 2013. Poverty and the Oppression of the Poor in Niger Delta (Isaiah 10:1-4):

A Theological Approach. International Journal of Humanities and Social Science 3, 11:236-265.

Parnell, S et al. 2002. Democratising Local Government: The South African Experiment. Cape Town: UCT Press.

Patel, R et al. 2002. Voices of the Poor: Can anyone help Us? New York: Oxford University Press.

Pazvakavambwa, S 2011. Addressing Food Security: A View from Multicultural Institutions, in Besada, H (ed.), Zimbabwe: Picking up the Pieces, 157-179. New York: Palgrave Macmillan.

Pinker, A 2009. Abomination to Egyptians in Genesis 43:32, 46:34, and Exodus 8:22. Old Testament Essays 22, 1:151-174.

Pleins, JD 1993. The Psalms: Songs of Tragedy, Hope and Justice. Maryknoll: Orbis.

Powell, I \& Thorneycroft, P 2010. Zimbabwe Diamonds are soaked in Blood: Locals used as Slaves as Military ignore Kimberly Requirements. Sunday Independent 12 December, 8.

Pritchard, BJ 1954. The Ancient Near East in Pictures relating to the Old Testament. Princeton: Princeton University Press.

Purvis, JD 1999. Exile and Return: From the Babylonian Destruction to the Reconstruction of the Jewish State, in Shanks, H (ed.), Ancient Israel: From Abraham to the Roman Destruction of the Temple, 150-175. Washington, DC: Biblical Archaeology Society.

Raath, J 2008) Harare Residents make do and use Boreholes as Water Supply dries up. The Herald 8 December, 6.

Raitt, AT 1977. A Theology of Exile. Philadelphia: Fortress.

Ringgren, H 1963. The Faith of the Psalmist. London: SCM. 
Rugwiji, T 2013. Appropriating Judean Postexilic Literature in a Postcolonial Discourse A Case for Zimbabwe. Unpublished PhD thesis. University of South Africa, Pretoria.

Rugwiji, T 2012. Reading the Exodus Liberation Motif in the Modern Post-Biblical World: The Zimbabwean Society and the Reality of Oppression. Saarbrücken: LAP Lambert Academic Publishing.

Rugwiji, T 2008. Reading the Exodus Tradition from a Zimbabwean Perspective. MA thesis, University of South Africa, Pretoria.

Rutherford, B 2011. On the Promise and Perils of Citizenship: Heuristic Concepts, Zimbabwean Example. Citizenship Studies 15, 3-4:499-512.

Sachs, JD \& Warner, AM 1996. Sources of Slow Growth in African Economies. Journal of African Economies 6, 3:335-376.

Sandu, N \& Mandizha, T 2017. Cash Crisis Takes a new Twist. The Standard 09 April.

Saunders, R 2011. Zimbabwe: Liberation Nationalism - Old and Born-again. RAPE $38: 127,126$.

Schader, JM 2010. A Spatial Reading of Psalms 46-48. Old Testament Essays 23, 1:139-160.

Schaper, J 1995. The Jerusalem Temple as an Instrument of the Achaemenid Fiscal Administration. Vetus Testamentum 45, 4:528-539.

Scheffler, EH 2001. Politics in Ancient Israel. Pretoria: Biblia.

Serfontein, JL 2012. An Old Testament Perspective on Imagining a Changing Society: Ezekiel as a Case Study. Unpublished PhD thesis, University of South Africa, Pretoria.

Smillie, I 2009. Zimbabwe, Diamonds and the Wrong Side of History. Partnership Africa Canada. Occasional Paper No. 8.

Smith, DL 1989. The Religion of the Landless: The Social Context of the Babylonian Exile. Bloomington: Meyer Stone Books.

Spangenberg, I 1992. The Job and the Powerless God, in Wessels, W \& Scheffler, EH (eds.), Old Testament Science and Reality, 304-316. Pretoria: Verba Vitae.

Stephens, S 1994. A Theology of Reconstruction: Nation-building and Human Rights Book Reviews. Online:

http://findarticles.com/p/articles/mi_m2065/is_n4_v46/ai_15918290/. Accessed June 3, 2012.

Sunderlin, WD, Angelsen, A \& Wunder, S (eds.) 2004. Forests and Poverty Alleviation. Jakarta: Centre for International Forestry Research.

Tapfumaneyi, R 2016. Zimbabwe: Point of Sale Machines at Weddings as Cash Crunch Bites. New Zimbabwe.com. 31 October.

Thompson, JA 1964. The Ancient Near Eastern Treaties and the Old Testament. London: The Tyndale Press.

Torrey, CC 1936. The Foundry of the Second Temple at Jerusalem. Journal of Biblical Literature 55, 4:247-260.

Torrey, CC 1943. The Evolution of a Financier in the Ancient Near East. Journal of Near Eastern Studies 2, 4:295-301. 
Ukpong, JS 1995. The Poor and the Mission of the Church in Africa, in Ukpong, JS (ed.), New Testament Essays. Lagos: Campbell Publishing 31-43.

Van Engen, C 1991. God's Missionary People: Rethinking the Purpose of the Local Church. Grand Rapids, MI: Baker.

Van Seters, J 1975. Abraham in History and Tradition. London: Yale

Vanderhooft, DS 2000. The Neo-Babylonian Empire and Babylonia in the Latter Prophets. Atlanta: Scholars.

Villa-Vicencio, C 1992. A Theology of Reconstruction: Nation-building and Human Rights. Cape Town: David Phillip.

Wall, T 2014. Sustainable Development Goals: New Targets hold Promise for Africa. Africa Renewal (United Nations Department of Public Information) 28, 3:26-28.

Walton, J 2006. Ancient Near Eastern Thought and the Old Testament: Introducing the Conceptual World of the Hebrew Bible. Grand Rapids: Baker Academic.

Waskow, A 1990. Exodus is not Enough. Cross Currents (Winter) 516-525.

Wenham, G 1979. The Book of Leviticus. Grand Rapids: Michigan.

Williamson, HGM 1985. Ezra, Nehemiah. Word Biblical Commentary. Waco: Word.

World Bank, 2001. World Development Report 2000/2001: The Fraying Web of Life. Washington, DC: World Resources Institute.

ZHRNF, (2010). Land reform and property rights in Zimbabwe. Harare: ZHRNF. 